\title{
Coordination Chemistry of 2,2'-Bipyridyl- and 2,2':6',2'- Terpyridyl-Substituted BEDT-TTFs: Formation of a Supramolecular Capsule Motif by the Iron(II) Tris Complex of 2,2'-Bipyridine-4-thiomethyl-BEDT-TTF.
}

Qiang Wang, ${ }^{\mathrm{a}} \quad$ Lee Martin, ${ }^{\mathrm{a}}$ Alexander J. Blake, ${ }^{\mathrm{b}}$ Peter Day, ${ }^{\mathrm{c}}$ Hiroki Akutsu ${ }^{\mathrm{d}}$ and John D. Wallis ${ }^{\mathrm{a}^{*}}$

${ }^{a}$ School of Science and Technology, Nottingham Trent University, Clifton Lane, Nottingham NG11 8NS, UK

${ }^{\mathrm{b}}$ School of Chemistry, The University of Nottingham, University Park, Nottingham NG7 2RD, UK

${ }^{c}$ University College London, Department of Chemistry, 20 Gordon Street, London WC1H 0AJ, UK

${ }^{d}$ Department of Chemistry, Graduate School of Science, Osaka University, 1-1 Machikaneyama-cho, Toyonaka, Osaka 560-0043, Japan

Abstract: Molecules of tris(2,2'-bipyridine-4-thiomethyl-BEDT-TTF)iron(II) (BEDT$\mathrm{TTF}=$ bis(ethylenedithio)tetrathiafulvalene) assemble in pairs to form a novel supramolecular capsular structure in the solid state. Three BEDT-TTF residues from one complex lie in the three grooves between coordinated bipyridines of the other complex, and vice versa, to form a capsule with three-fold rotational symmetry and an internal volume of $c a .160 \AA^{3}$. Further aspects of the coordination chemistry of this ligand, its 6substituted isomer and the 2,2':6'2''- terpyridyl-4'-thiomethyl-BEDT-TTF analogue are described. 


\section{Introduction.}<smiles>C1CSC2=C(S1)SC(=C1SC3=C(SCCS3)S1)S2</smiles>

1

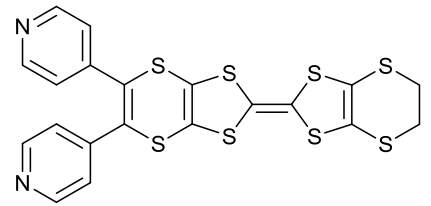

3

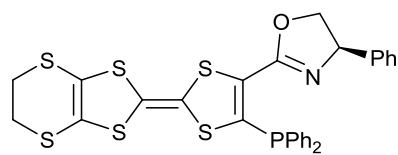

6

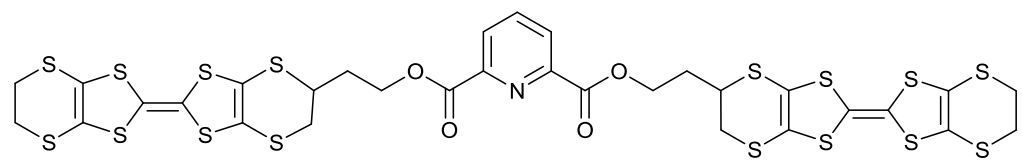

2

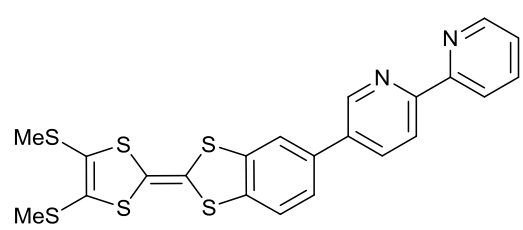

4

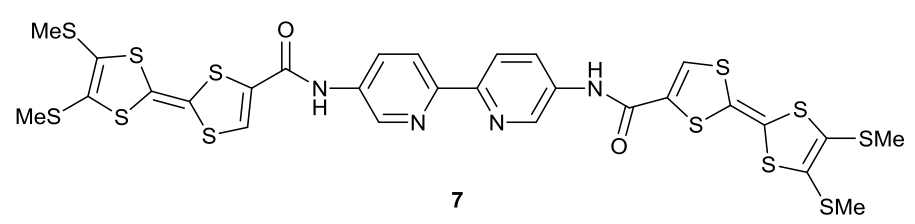<smiles>CN1N=C(c2cccc(C3=CSC(=C4SC=CS4)S3)n2)NN(C)C1=O</smiles>

Scheme 1: Molecular structures of BEDT-TTF 1 and TTF-, EDT-TTF and BEDT-TTF donors functionalized with metal binding groups 2-8.

BEDT-TTF 1 (Scheme 1) is a well-known organosulfur donor from which many radical cation salts and charge transfer compounds have been prepared. ${ }^{1}$ Its radical cation salts, prepared by electrocrystallisation or diffusion with an electron acceptor, exhibit a wide range of electrical properties including conductivity, semi-conductivity and the formation of low temperature superconductors such as (BEDT-TTF $)_{2}\left[\mathrm{Cu}(\mathrm{NCS})_{2}\right]^{2}{ }^{2}$ The salts have been intensively studied to gain a better understanding of their different 
electrical properties and the mechanisms underlying changes in those properties on variation of temperature or pressure, as well as to explore properties such as ferroelectricity $^{3}$ and thermopower. ${ }^{4}$ For any particular counterion there can exist different stoichiometries, polymorphs and solvates, with different electrical properties. For example, the 1:1 salt with triiodide has been exploited by combination with fullerene $\mathrm{C}_{60}$ to give a new conducting material, ${ }^{5}$ while the $\beta-2: 1$ salt has been incorporated in a pressure sensor ${ }^{6}$ and used for the production of superconducting nanoparticles. ${ }^{7}$ BEDTTTF is a component of several types of hybrid material such as paramagnetic superconductors prepared with iron(III) or ruthenium(III) tris-oxalates, ${ }^{8}$ and a material with coexisting conducting and ferromagnetic behavior composed of layers of BEDTTTF and mixed metal (Mn(II)/Cr(III)) honeycomb oxalate layers. ${ }^{9}$ BEDT-TTF has also formed salts with chiral anions, including induction of anion chirality through use of a chiral solvent. ${ }^{10}$

In the radical cation salts, the BEDT-TTF donors usually pack in layers, involving the formation of parallel stacks to give a two-dimensional conducting network via short $\mathrm{S} \cdots \mathrm{S}$ contacts, with different classes formed by variation in the orientation of the donors in the stack and between stacks as studied in detail by Mori. ${ }^{11}$ In contrast, layers composed of face-to-face pairs organized edge-to-face are observed in superconducting materials such as $(\mathrm{BEDT}-\mathrm{TTF})_{2}\left[\mathrm{Cu}(\mathrm{NCS})_{2}\right]\left(\right.$ Scheme 2). ${ }^{2}$ Addition of large substituents to the BEDT-TTF moiety mitigate against such packings, leading to pairing of donors, but two or more small substituents, e.g. methyl or hydroxymethyl, are tolerated. ${ }^{12}$ It is of note that while the oxidized BEDT-TTF derivatives usually have a 
planar organosulfur system, the neutral donors show more flexibility about the $S \cdots S$ vectors across the dithiole rings. ${ }^{13}$

(a)

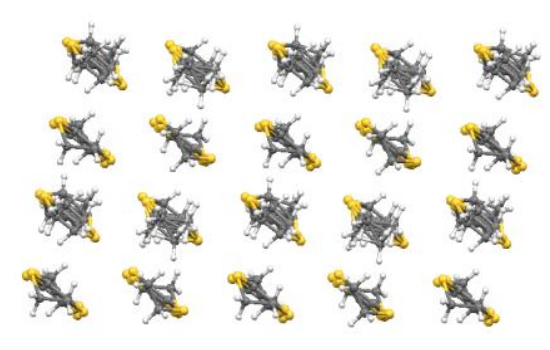

(b)

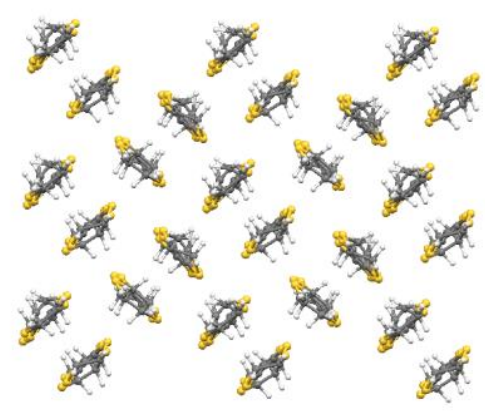

Scheme 2. Two examples of the donor packing arrangements within layers in the crystal structures of BEDT-TTF radical cation salts: (a) for $(\mathrm{BEDT}-\mathrm{TTF})_{2} \mathrm{~B}_{5} \mathrm{O}_{6}(\mathrm{OH})_{4}$, the $\beta$-type packing arrangement involves parallel stacks of tilted donors, (b) for (BEDT$\mathrm{TTF})_{2} \cdot \mathrm{Cu}(\mathrm{NCS})_{2}$ the $\kappa$-type packing involves perpendicular arrangements of pairs of face-to-face oriented donors. ${ }^{14}$

Although a wide range of functionalized BEDT-TTF derivatives, including chiral ones, has been reported in recent years ${ }^{15}$ there is only one molecule reported, 2 , which contains more than one BEDT-TTF moiety. ${ }^{16}$ Attachment of several BEDT-TTFs together has the potential to apply a constraint to the organization of the molecules in the solid state and lead to new crystal packing arrangements, and thus new physical properties, for their radical cation salts. One way of achieving this is to functionalize BEDT-TTF with a group capable of binding to a metal ion and then form bis or tris complexes around the metal, and finally oxidize such materials to their radical cation 
salts. Herein we report the production of a completely novel capsular motif by the tris iron(II) complex of BEDT-TTF functionalized with a 2,2'-bipyridine-4-thiomethyl group, $\mathbf{L}^{2}$, a ligand whose synthesis we have reported along with those of two other BEDT-TTFs: the 6-thiomethyl isomer $\mathbf{L}^{\mathbf{1}}$ and the 2,2':6'2"-terpyridyl derivative $\mathbf{L}^{\mathbf{3}}$ (Scheme 3). ${ }^{17}$ Other aspects of the coordination chemistry of this family of ligands are also reported. Other groups have attached metal binding groups to organosulfur donor molecules: a number of examples have involved pyridines or, in just a few cases, a 2,2'bipyridine or a 2,2':6', 2'-terpyridine as in $\mathbf{3 - 5 ,},{ }^{18}$ as well as phosphines ${ }^{19}$ and their combination with other metal binding groups as in $\mathbf{6},{ }^{20}$ and the use of 2,2 '-bipyridines as linkers between TTFs ${ }^{21}$ and between TTF and a verdazyl radical as in $\mathbf{7}$ and $\mathbf{8}$ (Scheme 2). ${ }^{22}$ Lorcy et al. have extensively reviewed these types of material and their coordination chemistries. ${ }^{23}$

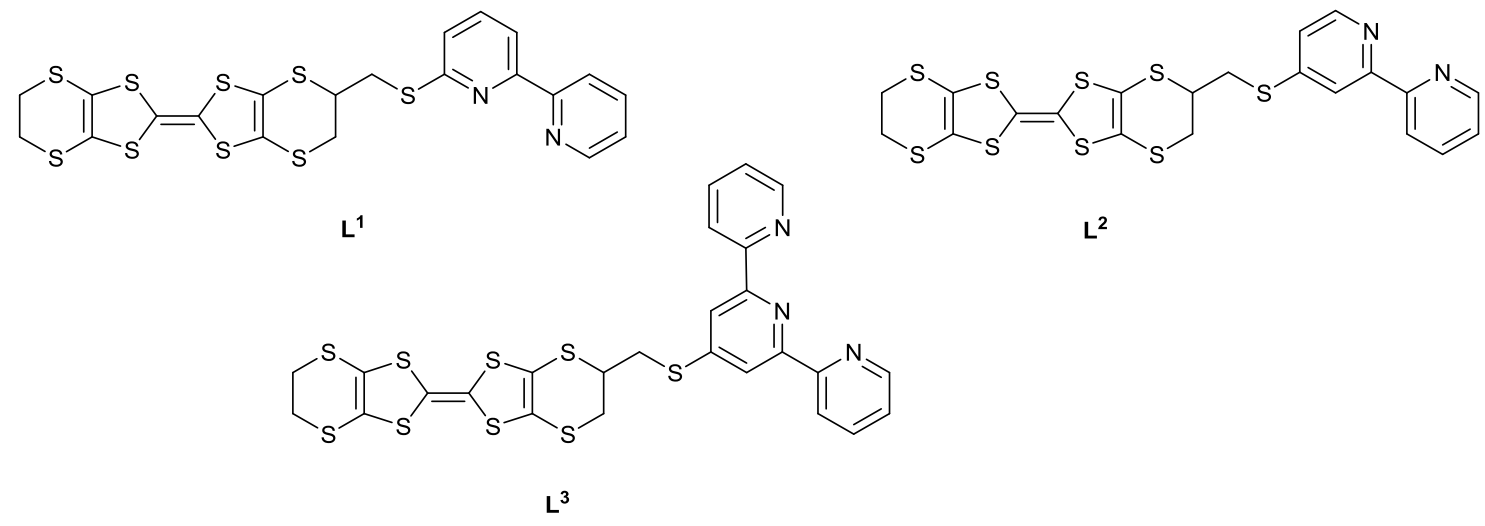

Scheme 3. Molecular structures of novel donors $\mathbf{L}^{\mathbf{1}}, \mathbf{L}^{\mathbf{2}}$ and $\mathbf{L}^{\mathbf{3}}$.

\section{Discussion.}

Tris complexes of ligand $\mathbf{L}^{2}$ with first row divalent transition metal cations ( $\mathrm{Mn}, \mathrm{Fe}$, $\mathrm{Co}, \mathrm{Ni}, \mathrm{Cu}, \mathrm{Zn}$ ) were prepared as their $\mathrm{PF}_{6}$ salts in $61-95 \%$ yields by refluxing a 
dichloromethane solution of three equivalents of the ligand $\mathbf{L}^{2}$ with a methanolic solution of the metal acetate, and precipitating the product by addition of ammonium hexafluorophosphate. Compositions were supported by microanalyses and observations of $\left[\mathrm{M}-\mathrm{PF}_{6}\right]^{+}$and/or $\left[\mathrm{M}-2 \mathrm{PF}_{6}\right]^{2+}$ ions in the electrospray mass spectra. After many attempts with these materials, solvated crystals of the tris complex with iron(II), $\left[\mathrm{Fe}\left(\mathbf{L}^{2}\right)_{3}\right]\left(\mathrm{PF}_{6}\right)_{2}$, were obtained by slow diffusion of methanol into a nitrobenzene solution, and their composition studied by single crystal X-ray diffraction. The crystal structure is quite remarkable; fac-complexes have crystallized together in pairs to form a capsule motif (Fig. 1). The unsubstituted "ends" of three electron-rich BEDT-TTF groups of one $\left[\mathrm{Fe}\left(\mathbf{L}^{2}\right)_{3}\right]^{2+}$ complex lie in the three grooves between the bipyridine groups around the iron cation of the other $\left[\mathrm{Fe}\left(\mathbf{L}^{2}\right)_{3}\right]^{2+}$ complex and vice versa. The resultant interlocking of BEDT-TTF units and tris(bipyridyl)Fe(II) groups produces a "molecular container" with internal volume of approximately $160 \AA^{3}$. This is a totally new packing behavior for the BEDT-TTF molecule.

Crystals of solvated $\left[\mathrm{Fe}\left(\mathbf{L}^{2}\right)_{3}\right]\left(\mathrm{PF}_{6}\right)_{2}$ are rhombohedral, space group $R-3$, with three capsule cations comprising six metals and eighteen ligands per unit cell, with the cation exhibiting crystallographic three-fold rotational symmetry with the rotation axis passing through the two iron centers generating a 50:50 mixture of $\Lambda$ and $\Delta$ forms related via a crystallographic inversion centre. Difference electron density maps indicate there is some electron density inside the capsule. However, there is also a very considerable amount of space between the capsules in the crystal structure, comprising $c a .40 \%$ of the 
unit cell volume, which is occupied by counterions (up to four per capsule) and solvents in a disordered way, for which no convincing structural model could be established. The
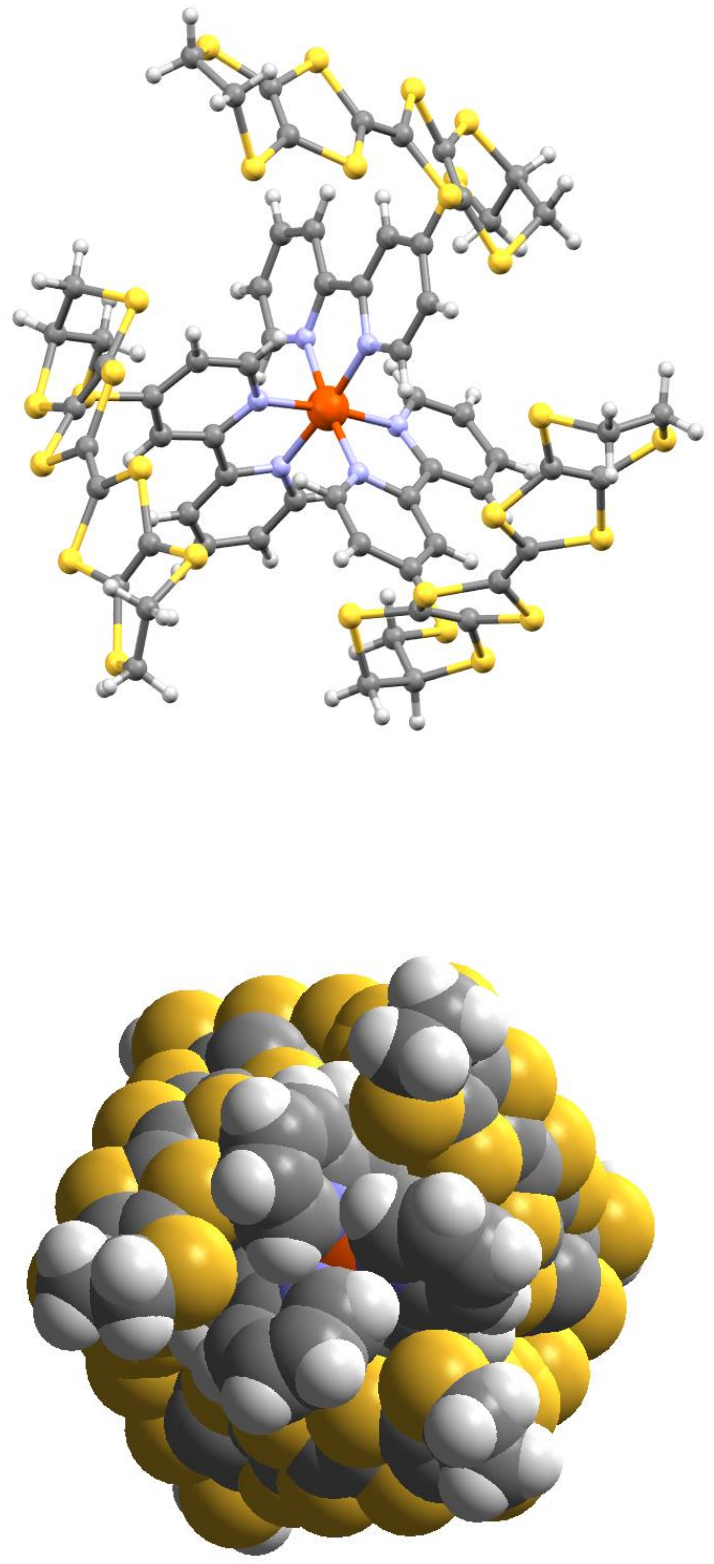

Figure 1. View of the $\left[\mathrm{Fe}\left(\mathbf{L}^{2}\right)_{3}\right]^{2+}$ complex with the three BEDT-TTF moieties directed forward (above), and view of the capsule $\left(\left[\mathrm{Fe}\left(\mathbf{L}^{2}\right)_{3}\right]_{2}\right)^{4+}$ down the three fold rotation axis, showing how the three BEDT-TTF groupings from one complex lie between the bipyridyl groups of the other. 


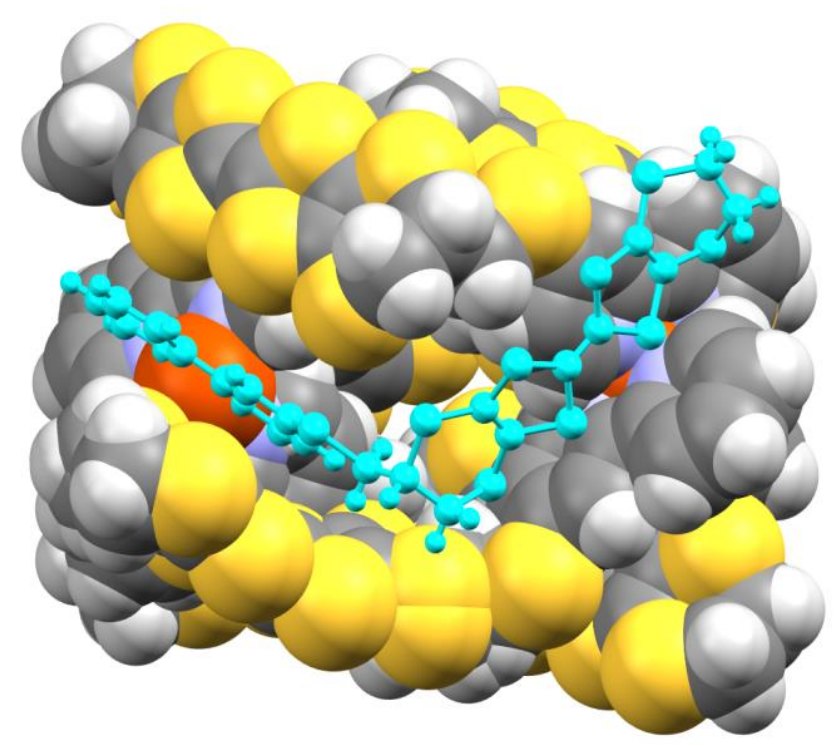

Figure 2. Space-filling view of the capsule with one ligand of $\mathbf{L}^{2}$ shown in ball-and-stick mode to give a view of the inside of the capsule and of how the ligand coordinates to one $\mathrm{Fe}(\mathrm{II})$ and then positions its BEDT-TTF fragment between two bipyridyl groups at the second Fe(II) center.

PLATON/SQUEEZE ${ }^{24}$ procedure was thus applied to the diffraction data, to exclude the solvent and the anions from the model. The results suggest $>3000$ electrons per unit cell in the inter-capsular space, and $c a .56$ electrons inside the capsule. We thus propose that the capsules are probably occupied by solvent (methanol) or in some cases by a $\mathrm{PF}_{6}{ }^{-}$anion (69 electrons). However, the limitations of the structural model do not justify a more detailed discussion of the contents. Nevertheless, despite the significant solvent and anion disorder, the cation geometry is well-defined.

The internal dimensions of the cavity of the capsule are $c a .6 \AA$ along the three-fold axis and $c a .7 \AA$ in directions perpendicular to this, corresponding to a volume $c a .160$ 
$\AA^{3}$. The $\mathrm{PF}_{6}{ }^{-}$anion has a volume of $c a \cdot 105 \AA^{3}$ and could feasibly be enclosed in a fraction of the capsules. The walls of the cavity are formed by the organosulfur portions of the substituted 1,3-dithiolo-1,4-dithiin units of six BEDT-TTF groups, and the capsule is closed top and bottom by the undersides of two tris(bipyridyl)Fe(II) units and their $-\mathrm{SCH}_{2}-$ linkages to the BEDT-TTF units (Fig. 2). The rest of the organosulfur residue of each BEDT-TTF wraps around the outside of the bipyridines. The structure accommodates both enantiomers of the racemic ligand $\mathbf{L}^{2}$ which contains a stereogenic centre at the point of attachment of the side chain to the BEDT-TTF moiety. For the two enantiomeric forms, the locations of the bipyridine and most of the BEDT-TTF group are coincident, which is achieved by modifying the conformation of the dithiin ring so that

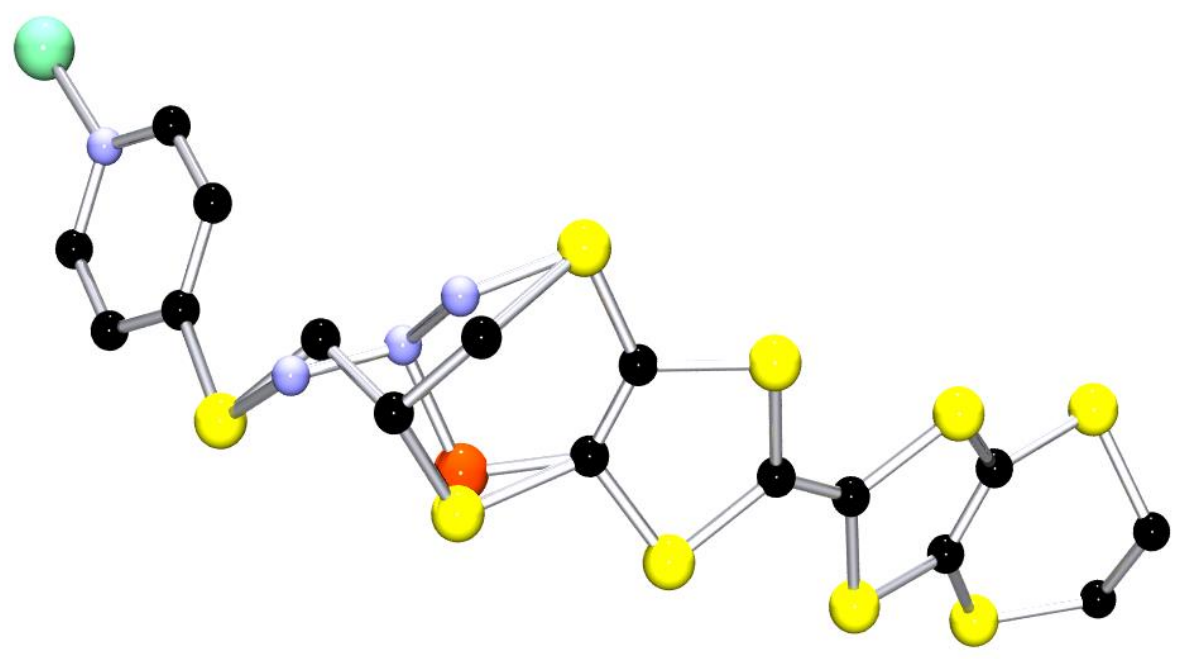

Figure 3. View showing how the two enantiomers of $\mathbf{L}^{2}$ are modeled, with the different positions for just the substituted ethylene bridge, side chain methylene group and one sulfur atom. Hydrogen atoms and a pyridine ring are omitted for clarity. 
the $-\mathrm{CH}_{2} \mathrm{~S}$ - side chain can take a pseudo-equatorial orientation for one enantiomer and a pseudo-axial orientation for the other enantiomer and so maintain very similar relative orientations of the BEDT-TTF and bipyridine units (Fig. 3). For a centrosymmetrically related ligand (space group $R-3$ ), there will be an opposite assignment of chirality to the pseudo-equatorial and pseudo-axial conformations.

The BEDT-TTF groups forming the capsule walls are slightly curved, with the central $\mathrm{S}_{2} \mathrm{C}=\mathrm{CS}_{2}$ fragment of the TTF ring very nearly planar but with flexings of $14.9^{\circ}$ and $20.2^{\circ}$ about the $S \cdots S$ vectors across the two dithiole rings, so that the dithiin sulfur atoms are displaced inwards from the central $\mathrm{S}_{2} \mathrm{C}=\mathrm{CS}_{2}$ plane by $0.717-1.134 \AA$. The capsule formation is stabilized by interactions between the electron-deficient pyridine rings and the electron-rich BEDT-TTF groups belonging to the opposite iron complex. The unsubstituted "half" of each organosulfur donor lies in the cleft between two bipyridine rings making contact with one bipyridine system "face to face", and directing its edge to the face of the second bipyridine ring (Fig. 2). One dithiole S atom, S4, is central to both interactions (Fig. 4). For the face-to-face interaction, this dithiole $\mathrm{S}$ atom lies over the center of the substituted pyridine ring at a perpendicular separation of 3.537 $\AA$ from its best plane, with shortest C $\cdots \mathrm{C}$ contacts between the dithiole and pyridine rings of 3.429 and $3.512 \AA$. The terminal dithiin S atom, S2, lies over the space between

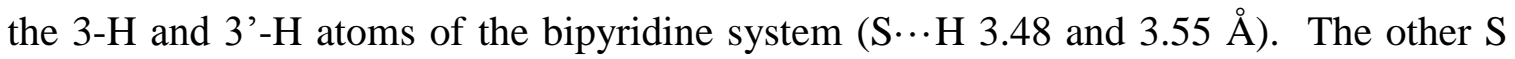
atom in the dithiole ring, S3, makes a S $\cdots S$ contact of $3.780 \AA$ with the side-chain $\mathrm{S}$ atom connected to the pyridine ring. The edge of the donor makes shorter contacts to the face of the second bipyridine ring. Thus, dithiole sulfur atom S4 lies over the unsubstituted 
pyridine ring at $3.312 \AA$ above the best plane through the ring, with two particularly short S $\cdots C$ contacts of 3.436 and $3.437 \AA$, respectively, to the 5- and 6-C atoms of that pyridine ring. The observation of shorter $S \cdots C$ contacts from the edge of the donor rather than from its face is in accord with the asymmetric shape of the bonded divalent sulfur atom. ${ }^{25}$ The edge-to-face contact is completed by sulfur atoms from the next dithiole and dithiin rings, S6 and S8, which lie 3.441 and $3.327 \AA$, respectively, from the bipyridine plane, but the former is oriented over the space between the two 3- and 3'- hydrogen atoms $(\mathrm{S} \cdots \mathrm{H} 3.66$ and $3.70 \AA)$ and the latter lies close to the bond from the pyridine ring to the side chain $\mathrm{S}$ atom $(\mathrm{S} \cdots \mathrm{C} 3.624, \mathrm{~S} \cdots \mathrm{S} 3.706 \AA$ ). The $\mathrm{Fe}-\mathrm{N}$ distances of $1.955(3)$ and $1.971(3) \AA$ are typical for a low spin Fe(II) tris(bipy) complex $(1.96 \pm 0.04 \AA) .{ }^{26}$

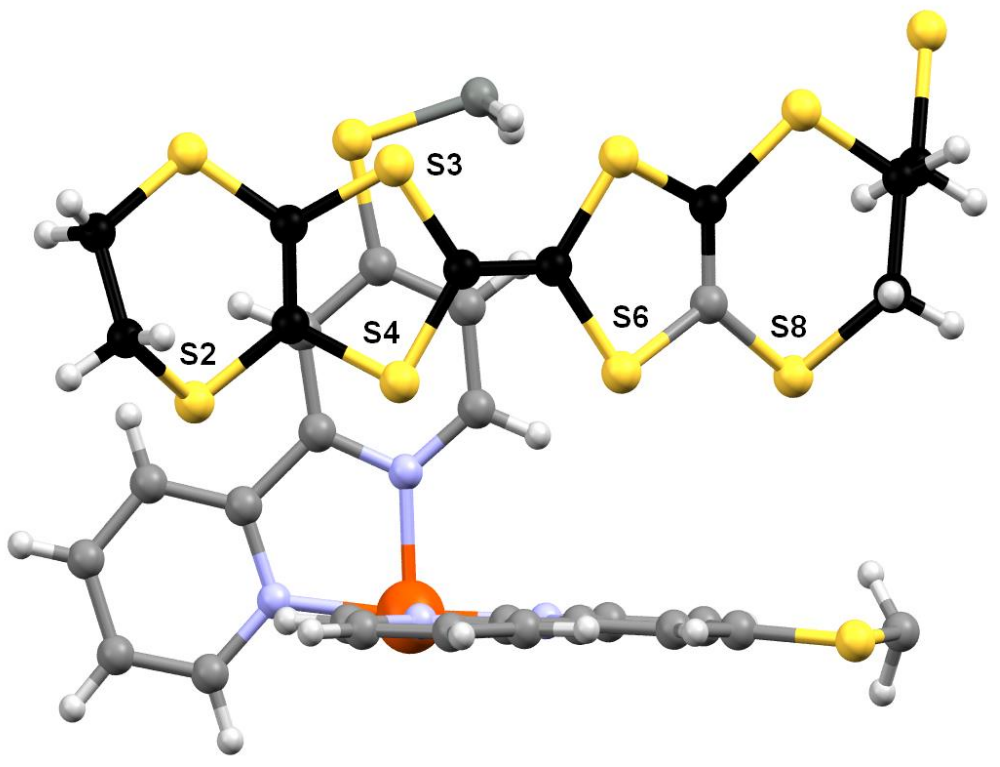

Figure 4. Disposition of one BEDT-TTF residue in the cleft between two bipyridine rings in $\left(\left[\mathrm{Fe}\left(\mathbf{L}^{2}\right)_{3}\right]\right)_{2}{ }^{4+}$. BEDT-TTF residues are omitted from the bipyridines and viceversa for clarity. 
There are no particularly short $\mathrm{S} \cdots \mathrm{S}$ contacts between donor moieties within the capsule, the shortest being 3.706(3) $\AA$ between a dithiin $\mathrm{S}$ atom and the side chain $\mathrm{S}$ of another BEDT-TTF unit. The shortest inter-capsule S $\cdots S$ contacts involve dithiole $S$ atoms, and the three shortest lie in the range 3.594-3.648 $\AA$.

Cyclic voltammetry of this series of complexes shows very similar oxidation potentials to BEDT-TTF with first and second oxidations typically at 0.56 and $0.88 \mathrm{~V}$ relative to $\mathrm{Ag} / \mathrm{AgCl}$ (Table $\mathrm{S} 1$ ). Room temperature magnetic moments were also recorded (Table S2), and are consistent with those of $\operatorname{tris}\left(2,2\right.$ '-bipyridyl) complexes. ${ }^{27} \mathrm{Fe}$ tris-bipyridine and its derivatives are well known to adopt low spin $(\mathrm{S}=0)$ configurations with the high spin configuration only accessible as a short-lived excited state identified by femtosecond spectroscopy. $^{26}$ Variable temperature magnetic studies on $\left[\mathrm{Fe}\left(\mathbf{L}^{2}\right)_{3}\right]\left(\mathrm{PF}_{6}\right)_{2}$ revealed a weak Curie tail corresponding to trace paramagnetic impurity (ca. $1.2 \% S=2$ high spin $\mathrm{Fe}^{\mathrm{II}}$ or $0.8 \% S=5 / 2 \mathrm{Fe}^{\mathrm{III}}$ ) coupled with a component arising from temperature independent paramagnetism (TIP). The exact value of the TIP term is difficult to determine due to uncertainty in the diamagnetic correction (residual lattice solvent, gelatin capsule etc.) but is of the order of $10^{-3} \mathrm{emu} \cdot \mathrm{mol}^{-1}$.

Although there is an extensive literature on the formation of molecular capsules, ${ }^{28}$ to our knowledge none have been reported where the walls are formed mainly by organosulfur donors. Nevertheless, TTF-related species have found application in the preparation of cavitands, carcerands and also as functionalities for calixarene based sensors $^{29}$ and supramolecular applications of TTF have been reviewed. ${ }^{30}$ 


\section{Further coordination chemistry of ligand $\mathbf{L}^{2}$.}

Ligand $\mathbf{L}^{2}$ shows further coordination chemistry, for example forming 1:1 complexes with $\mathrm{M}(\mathrm{hfac})_{2}(\mathrm{M}=\mathrm{Mn}, \mathrm{Co}, \mathrm{Ni}, \mathrm{Cu}, \mathrm{Zn})^{31}$ to give six-coordinate $\left[\left(\mathbf{L}^{\mathbf{2}}\right) \mathrm{M}(\mathrm{hfac})_{2}\right]$ complexes in $70-80 \%$ yield, and with $\mathrm{Nd}(\mathrm{hfac})_{3}$ to give the eight-coordinate $1: 1$ complex $\left[\left(\mathbf{L}^{2}\right) \mathrm{Nd}(\mathrm{hfac})_{3}\right]$ in $80 \%$ yield. The formulations of the complexes are supported by chemical analyses, and their mass spectra typically show peaks at $m / z$ : $[\mathrm{M}-\mathrm{hfac}]^{+}$. The $\left[\left(\mathbf{L}^{2}\right) \mathrm{M}(\mathrm{hfac})_{2}\right]$ complexes showed very similar cyclic voltammetry data to BEDTTTF (Table S1), suggesting that coordination is taking place only at the $\mathrm{N}$ atoms, and that the materials are simple octahedral complexes with one bipyridine and two hfac ligands (Scheme 4). The magnetic moment of the complex with $\mathrm{Co}(\mathrm{II})$ is consistent with the lower ligand field strength of a $\left[\mathrm{M}(\right.$ bipy $\left.)(\mathrm{hfac})_{2}\right]$ complex compared to that in the tris $\left(\mathbf{L}^{2}\right)$ complex (Table S2). Ligand $\mathbf{L}^{2}$ also formed $\left(\mathbf{L}^{2}\right)_{2} \mathrm{MnCl}_{2}$, a 2:1 complex with $\mathrm{MnCl}_{2}$, which is assigned as the cis complex by analogy with similar cases, ${ }^{32}$ and also $\mathbf{L}^{2} \mathrm{CuCl}_{2}$, a 1:1 complex with $\mathrm{CuCl}_{2}$.
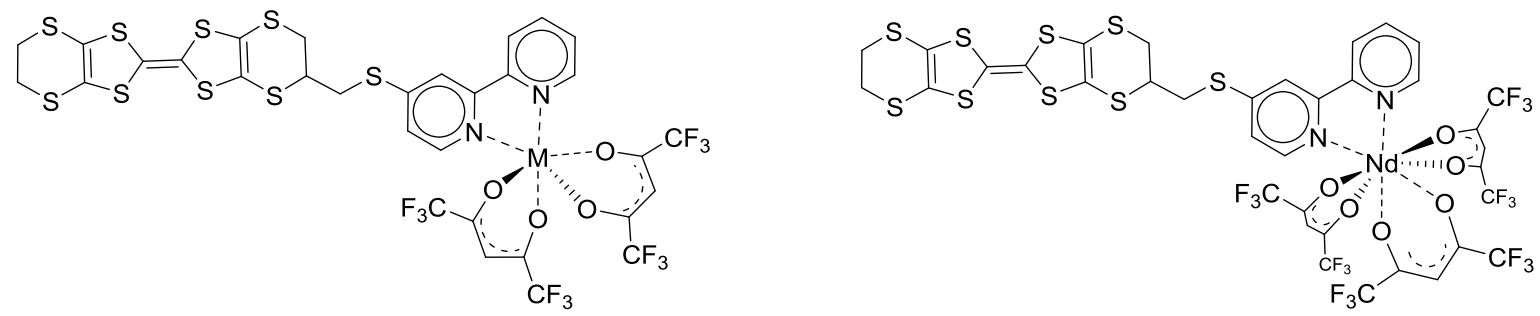

$M=M n(I I), C o(I I), N i(I I), C u(I I), Z n(I I)$

Scheme 4: $\quad\left[\left(\mathbf{L}^{2}\right) \mathrm{M}(\mathrm{hfac})_{2}\right]$ complexes with divalent transition metal ions and the $\left[\left(\mathbf{L}^{2}\right) \mathrm{M}(\mathrm{hfac})_{3}\right]$ complex with $\mathrm{Nd}(\mathrm{III})$. 


\section{Chemistry and crystal structure of 6-substituted bipyridyl ligand $\mathbf{L}^{\mathbf{1}}$.}
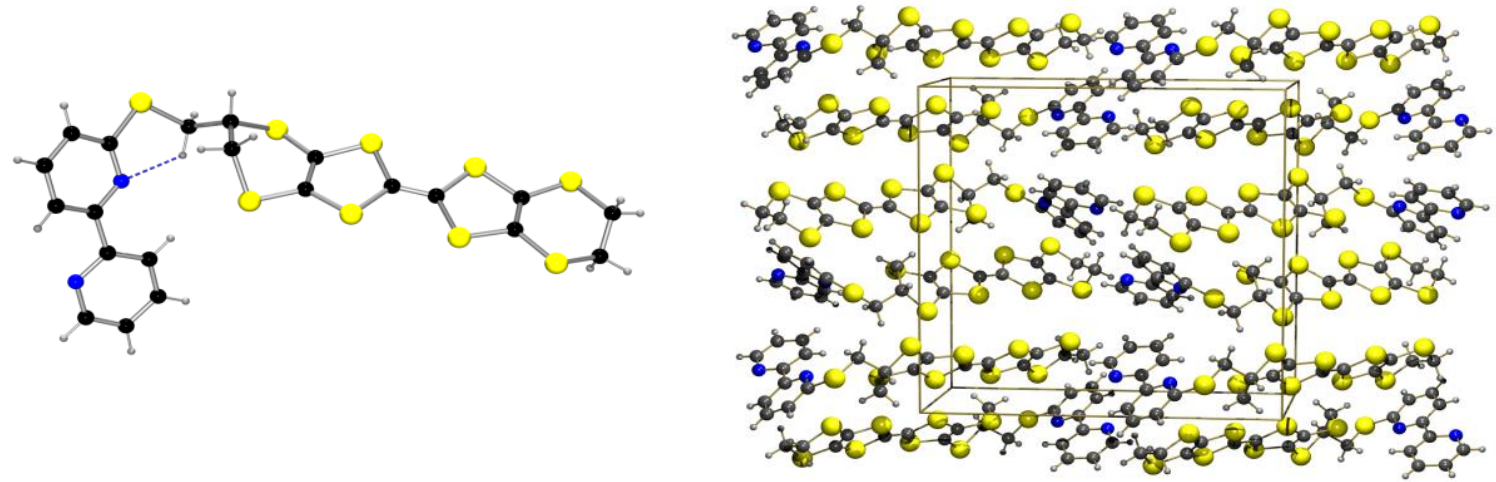

Figure 5. The molecular and crystal structures of ligand $\mathbf{L}^{\mathbf{1}}$ showing the weak $1,5 \mathrm{~N} \cdots \mathrm{H}$ interaction (left) and the segregation of BEDT-TTF and bipyridine units (right).

In contrast to $\mathbf{L}^{2}$, it was not possible to isolate any stable complexes containing ligand $\mathbf{L}^{\mathbf{1}}$, in which the BEDT-TTF- $\mathrm{CH}_{2}-\mathrm{S}$ - side chain is attached to the 6-position of the bipyridine, in conditions which were successful for ligand $\mathbf{L}^{\mathbf{2}}$. 6-Substitution does not necessarily prevent a bipyridine from coordinating. ${ }^{33}$ In the crystal structure of ligand $\mathbf{L}^{1}$ (Fig. 5) the side chain lies in a pseudo-equatorial position from the dithiin ring which adopts an approximate boat type conformation. The $-\mathrm{S}-\mathrm{CH}_{2}-$ group takes an extended conformation and links to the trans-bipyridine system so that the $\mathrm{S}-\mathrm{CH}_{2}$ bond lies roughly syn to the adjacent $\mathrm{CN}$ bond of the pyridine ring. This leads to a short $(1,5)$ $\mathrm{N} \cdots \mathrm{H}$ contact of $2.37 \AA$ between the ring $\mathrm{N}$ atom and the side chain methylene group; this weak hydrogen bond will be enhanced by electron donation from the side chain sulfur atom to the ring nitrogen atom. The pyridine and organosulfur residues are more or less segregated in the crystal structure. The lack of stability of complexes of $\mathbf{L}^{1}$ may be 
due to a number of factors including the bulk of the BEDT-TTF group and the weak intramolecular interaction discussed above. Furthermore, there may be a kinetic factor, since these large organosulfur units may aggregate in solution and shield the pyridine nitrogen atom from potential coordination sites. Unusual and unexpected chemistry has been observed before with the BEDT-TTF system. ${ }^{17,34}$

\section{Coordination chemistry of terpyridyl ligand $L^{3}$.}

As a comparison to $\mathbf{L}^{2}$, the coordination chemistry of ligand $\mathbf{L}^{3}$, which carries a terpyridyl ligand, with first row transition metals has also been investigated. Bis complexes of ligand $\mathbf{L}^{3}$ with $\mathrm{M}(\mathrm{II})(\mathrm{M}=\mathrm{Mn}, \mathrm{Fe}, \mathrm{Co}, \mathrm{Ni}, \mathrm{Cu}, \mathrm{Zn})$ were prepared in 57$82 \%$ yields by refluxing a dichloromethane solution of two equivalents of the ligand with a methanolic solution of the metal acetate, followed by precipitation of the product with ammonium hexafluorophosphate. Compositions were supported by microanalyses, but we were unable to grow suitable crystals for structural characterization, possibly due to the presence of two diastereomers. It would be expected that the two terpyridyl groups would be roughly perpendicular to each other (Scheme 5). The cyclic voltammetry of these complexes shows that first oxidation potentials are $c a .0 .03 \mathrm{~V}$ higher and the second oxidation potentials are $c a .0 .08 \mathrm{~V}$ lower than those for BEDT-TTF (Table S1). The room temperature magnetic moments of the complexes are consistent with the higher ligand field of bis(terpy) complexes (Table S2). ${ }^{35}$ The magnetic measurement of the Fe(II) complex showed similar behavior to the tris- $\mathbf{L}^{2}$ derivative, i.e comprising a small concentration of a paramagnetic defect $\left(0.6 \%\right.$ high spin $\left.\mathrm{Fe}^{\mathrm{II}}\right)$ and a temperature 
independent paramagnetism term of a comparable magnitude to that observed for the $\operatorname{tris}\left(\mathbf{L}^{2}\right) \mathrm{Fe}(\mathrm{II})$ complex.

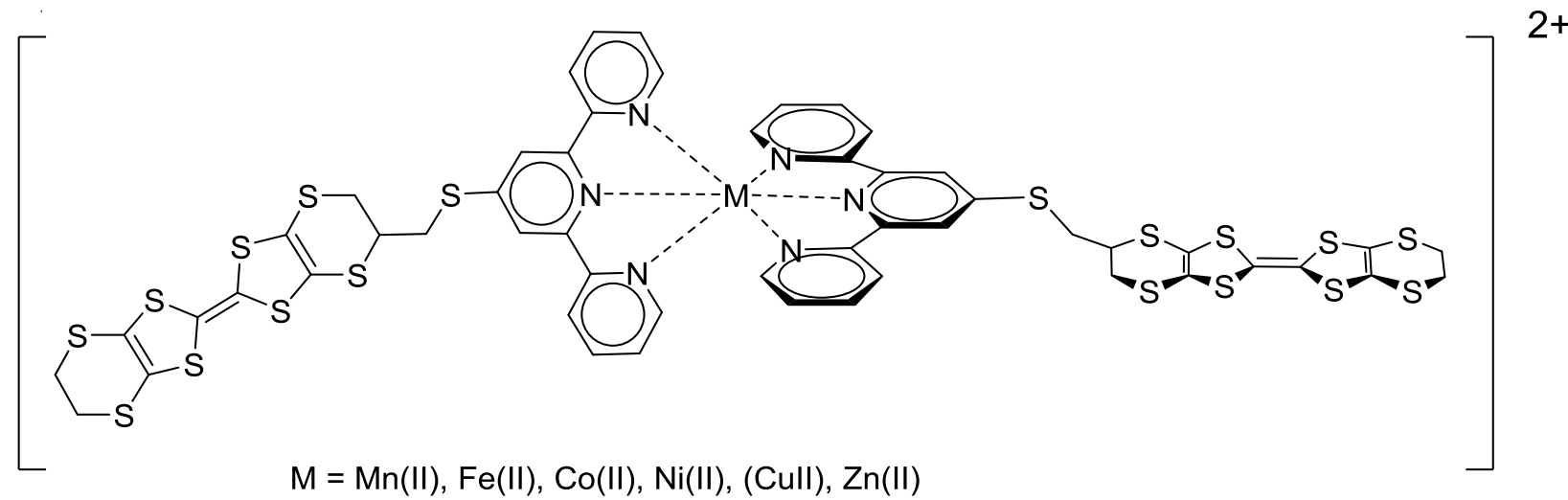

Scheme 5: Bis-complexes of ligand $\mathbf{L}^{3}$ with divalent transition metal ions.

\section{Conclusion.}

We have demonstrated that ligand $\mathbf{L}^{2}$ is capable of forming a molecular capsule with $\mathrm{Fe}(\mathrm{II})$ when the counterion is $\mathrm{PF}_{6}{ }^{-}$. Two tris complexes of formula $\left[\mathrm{Fe}\left(\mathbf{L}^{2}\right)_{3}\right]^{2+}$ combine together with the three electron-rich organosulfur donors of one complex lying in the electron deficient grooves between the bipyridine groups of the other to form the capsule, and vice versa. The encapsulated volume could accommodate a $\mathrm{PF}_{6}{ }^{-}$ion but this could not unambiguously be confirmed from the X-ray structure determination. The capsular framework structure can accommodate either enantiomer of ligand $\mathbf{L}^{2}$ at each site, by adjusting the conformation of the substituted dithiin ring, so that the side chain lies either pseudo-equatorial of pseudo-axial. The corresponding complexes with first row divalent metal ions $\mathrm{Mn}$ (II) and $\mathrm{Co}(\mathrm{II})-\mathrm{Zn}$ (II) were prepared and may also possess 
analogous structures, but we were unable to obtain crystals suitable for measurement. The oxidation potentials of the ligand are not affected by formation of these structures. Ligand $\mathbf{L}^{2}$ behaves as a typical 4-substituted bipy ligand, forming complexes of type $\left[\left(\mathbf{L}^{2}\right) \mathrm{M}(\mathrm{hfac})_{2}\right](\mathrm{M}=\mathrm{Mn}(\mathrm{II}), \mathrm{Co}(\mathrm{II})-\mathrm{Zn}(\mathrm{II}))$ and $\left[\left(\mathbf{L}^{2}\right)_{2} \mathrm{MnCl}_{2}\right]$, while its 6-substituted isomer did not form any complexes at all with divalent first row transition metal ions. The corresponding 4'-substituted terpy ligand formed bis complexes of type $\left[\left(\mathbf{L}^{\mathbf{3}}\right)_{2} \mathrm{M}\right]\left(\mathrm{PF}_{6}\right)_{2}(\mathrm{M}=\mathrm{Mn}(\mathrm{II})-\mathrm{Zn}(\mathrm{II}))$ in which the ligand had a slightly higher first oxidation potential than BEDT-TTF.

The novel capsular structure of the complex $\left[\left(\mathbf{L}^{2}\right)_{3} \mathrm{Fe}(\mathrm{II})\right]_{2}{ }^{4+}$ opens up the possibility of new applications of the structurally flexible BEDT-TTF unit. Extension of the chains linking the bipyridine ring and BEDT-TTF group, for example by including aromatic rings, offers the opportunity to encapsulate larger species e.g. fullerenes. Tris(BEDT-TTF)-functionalization of a template which did not stabilize capsule formation could lead to a species capable of accepting large electron-deficient species. Furthermore, the opportunity to address the BEDT-TTF units electrochemically offers the chance to bind or release such species. The preparation of charge transfer salts of the complexes described herein is in progress. 


\section{Experimental.}

General. NMR spectra were measured on a JEOL ECLIPSE 400 spectrometer at 400 $\mathrm{MHz}$ for ${ }^{1} \mathrm{H}$ and at $100 \mathrm{MHz}$ for ${ }^{13} \mathrm{C}\left\{{ }^{1} \mathrm{H}\right\}$ using $\mathrm{CDCl}_{3}$ as solvent and tetramethylsilane (TMS) as standard unless otherwise stated, and measured in p.p.m. downfield from TMS with coupling constants reported in Hz. IR spectra were recorded on a Perkin Elmer

Spectrum $100 \mathrm{FT}$-IR Spectrometer as $\mathrm{KBr}$ disks and are reported in $\mathrm{cm}^{-1}$. Mass spectra were recorded at the EPSRC Mass Spectrometry Centre at the University of Swansea. Chemical analysis data were obtained from Mr Stephen Boyer, London Metropolitan University. Flash chromatography was performed on 40-63 silica gel (Merck). Ligands $\mathbf{L}^{\mathbf{1}}-\mathbf{L}^{\mathbf{3}}$ were prepared according to the procedures previously reported. ${ }^{17}$ Cyclic voltammetry measurements were made using an $\mu$ Autolab type II from Metrohm Autolab B.V. Magnetic susceptibility measurements were performed with a Quantum Design MPSM2 SQUID magnetometer using randomly oriented polycrystalline material encased in aluminium foil at 0.1 Tesla.

\section{Preparation of $\left[\mathrm{M}\left(\mathrm{L}^{2}\right)_{3}\right]\left(\mathrm{PF}_{6}\right)_{2}$.}

[Zn( $\left(\mathbf{L}^{2}\right)$ 3] $\left(\mathbf{P F}_{\mathbf{6}}\right)_{2}$. A solution of zinc acetate $(0.010 \mathrm{~g}, 0.046 \mathrm{mmol})$ in $\mathrm{MeOH}(2 \mathrm{~mL})$ was added to a solution of ligand $\mathbf{L}^{2}(0.081 \mathrm{~g}, 0.14 \mathrm{mmol})$ in $\mathrm{CH}_{2} \mathrm{Cl}_{2}(7 \mathrm{~mL})$ and the mixture refluxed for $2 \mathrm{~h}$. After stirring at room temperature overnight, addition of $\mathrm{NH}_{4} \mathrm{PF}_{6}(0.031$ $\mathrm{g}, 0.19 \mathrm{mmol})$ in $\mathrm{MeOH}(3 \mathrm{~mL})$ gave instant formation of yellow precipitate which was stirred for a further $1 \mathrm{~h}$. The yellow solid was collected by filtration, washed with $\mathrm{MeOH}$ and then $\mathrm{CH}_{2} \mathrm{Cl}_{2}$ and dried under vacuum. Yield $0.070 \mathrm{~g}$ (72\%). Calc. for $\mathrm{C}_{63} \mathrm{H}_{48} \mathrm{~F}_{12} \mathrm{~N}_{6} \mathrm{P}_{2} \mathrm{~S}_{27} \mathrm{Zn} \cdot \mathrm{H}_{2} \mathrm{O}, \mathrm{C} 35.55, \mathrm{H} 2.37, \mathrm{~N} 3.95 \%$, found C 35.40, H 2.28, N 3.64\%; 
$m / z\left(\mathrm{ES}^{+}\right) 1965\left[\mathrm{M}-\mathrm{PF}_{6}\right]^{+}, 910\left[\mathrm{M}-2 \mathrm{PF}_{6}\right]^{2+} ; v_{\max }(\mathrm{KBr}): 1592,1571,1437,1408,1016$ 842, 788, $558 \mathrm{~cm}^{-1} ;{ }^{1} \mathrm{H}$ NMR (DMSO-d 6 ): $\delta=7.35-8.90$ (br, m, 21H, Ar- $H_{21}$ ), 4.12 (br, $3 \mathrm{H}, \mathrm{SCHCH} 2), 3.25-3.95\left(\mathrm{~m}, 24 \mathrm{H}, 12 \mathrm{xCH}_{2}\right) ;{ }^{31} \mathrm{P}\left\{{ }^{1} \mathrm{H}\right\} \quad \mathrm{NMR}\left(\mathrm{DMSO}-\mathrm{d}_{6}\right): \delta=-142.84$ (septet, $J_{\mathrm{F}-\mathrm{P}}=711 \mathrm{~Hz}, \mathrm{PF}_{6}{ }^{-}$). The product was insoluble in normal organic solvents except DMSO. The following complexes were prepared following the same general procedure:

$\left[\mathbf{M n}\left(\mathbf{L}^{2}\right)_{3}\right]\left(\mathbf{P F}_{6}\right)_{2}$ : yellow solid, yield 61\%; Calc. for $\mathrm{C}_{63} \mathrm{H}_{48} \mathrm{~F}_{12} \mathrm{MnN}_{6} \mathrm{P}_{2} \mathrm{~S}_{27}, \mathrm{C} 36.04, \mathrm{H}$ 2.30, N 4.00\%, found C 35.79, H 2.27, N 3.77\%; m/z $\left(\mathrm{ES}^{+}\right) 1955\left[\mathrm{M}-\mathrm{PF}_{6}\right]^{+}, 904[\mathrm{M}-2$ $\left.\mathrm{PF}_{6}\right]^{2+} ; v_{\max }(\mathrm{KBr}): 1590,1570,1436,1407,843,789,558 \mathrm{~cm}^{-1}$.

$\left[\mathbf{F e}\left(\mathbf{L}^{2}\right)_{3}\right]\left(\mathbf{P F}_{6}\right)_{2}$ : from iron(II) chloride, purple solid, yield 70\%; Calc. for $\mathrm{C}_{63} \mathrm{H}_{48} \mathrm{~F}_{12} \mathrm{FeN}_{6} \mathrm{P}_{2} \mathrm{~S}_{27}, \mathrm{C} 36.02, \mathrm{H} 2.30, \mathrm{~N} 4.00 \%$, found C 35.69, H 2.33, N 3.68\%; m/z $\left(\mathrm{ES}^{+}\right) 904.9\left[\mathrm{M}-2 \mathrm{PF}_{6}\right]^{2+} ; v_{\max }(\mathrm{KBr}): 1597,1466,1437,1407,843,784,558 \mathrm{~cm}^{-1}$.

$\left[\mathbf{C o}\left(\mathbf{L}^{2}\right) 3\right]\left(\mathbf{P F}_{6}\right)_{2}$ : brown-yellow solid, yield 95\%; Calc. for $\mathrm{C}_{63} \mathrm{H}_{48} \mathrm{CoF}_{12} \mathrm{~N}_{6} \mathrm{P}_{2} \mathrm{~S}_{27}, \mathrm{C} 35.97$, H 2.30, N 3.99\%, found C 36.37, H 2.23, N 3.89\%; m/z $\left(\mathrm{ES}^{+}\right) 1959\left[\mathrm{M}-\mathrm{PF}_{6}\right]^{+}, 907[\mathrm{M}-2$ $\left.\mathrm{PF}_{6}\right]^{2+} ; v_{\max }(\mathrm{KBr}): 1592,1570,1534,1472,1437,1409,842,788,773,558 \mathrm{~cm}^{-1}$.

$\left[\mathbf{N i}\left(\mathbf{L}^{2}\right)_{3}\right]\left(\mathbf{P F}_{6}\right)_{2}$ : brown-yellow solid, yield 76\%; Calc. for $\mathrm{C}_{63} \mathrm{H}_{48} \mathrm{~F}_{12} \mathrm{~N}_{6} \mathrm{NiP}_{2} \mathrm{~S}_{27} . \mathrm{H}_{2} \mathrm{O}, \mathrm{C}$ 35.67, H 2.38, N 3.96\%, found C 35.36, H 2.21, N 3.67\%; m/z $\left(\mathrm{ES}^{+}\right) 1959\left[\mathrm{M}-\mathrm{PF}_{6}\right]^{+}, 907$ $\left[\mathrm{M}-2 \mathrm{PF}_{6}\right]^{2+} ; v_{\max }(\mathrm{KBr}): 1593,1570,1438,1406,842,788,558 \mathrm{~cm}^{-1}$.

$\left[\mathbf{C u}\left(\mathbf{L}^{2}\right)\right.$ 3] $\left(\mathbf{P F}_{6}\right)_{2}$ : light-brown solid, yield 79\%; Calc. for $\mathrm{C}_{63} \mathrm{H}_{48} \mathrm{CuF}_{12} \mathrm{~N}_{6} \mathrm{P}_{2} \mathrm{~S}_{27}, \mathrm{C} 35.89, \mathrm{H}$ 2.29, N 3.99\%, found C35.66, H 2.28, N 3.71\%; m/z $\left(\mathrm{ES}^{+}\right) 1962\left[\mathrm{M}-\mathrm{PF}_{6}\right]^{+} ; v_{\max }(\mathrm{KBr})$ : $1595,1570,1438,1406,843,788,558 \mathrm{~cm}^{-1}$. 


\section{Synthesis of $\left[\left(\mathrm{L}^{2}\right) \mathrm{M}(\mathrm{hfac})_{2}\right]$ complexes.}

$\left[\left(\mathbf{L}^{2}\right) \mathbf{Z n}(\mathbf{h f a c})_{2}\right]$ A solution of $\mathbf{L}^{2}(0.074 \mathrm{~g}, 0.13 \mathrm{mmol})$ in $\operatorname{dry} \mathrm{CH}_{2} \mathrm{Cl}_{2}(10 \mathrm{~mL})$ was added to a solution of $\mathrm{Zn}(\mathrm{hfac})_{2} \cdot 2 \mathrm{H}_{2} \mathrm{O}(0.065 \mathrm{~g}, 0.13 \mathrm{mmol})$ in dry acetone $(3 \mathrm{~mL})$ and the solution was heated to reflux for $1 \mathrm{~h}$ under nitrogen followed by stirring for $20 \mathrm{~h}$. at RT. Removal of solvents gave an orange solid which was extracted with $\mathrm{Et}_{2} \mathrm{O}$. Removal of $\mathrm{Et}_{2} \mathrm{O}$ from the filtrate afforded an orange solid which was recrystallized from $\mathrm{CH}_{2} \mathrm{Cl}_{2} / \mathrm{n}$ hexane to give $\left[\mathrm{Zn}\left(\mathbf{L}^{2}\right)(\mathrm{hfac})_{2}\right]$ as an orange powder (yield $0.12 \mathrm{~g}, 85 \%$ ). Calc. for $\mathrm{C}_{31} \mathrm{H}_{18} \mathrm{~N}_{2} \mathrm{O}_{4} \mathrm{~F}_{12} \mathrm{~S}_{9} \mathrm{Zn}$ : C 34.98, H 1.70, N 2.63\%; found C 35.21, H 1.78, N 2.43\%; $v_{\max }$ (KBr): 1648, 1607, 1594, 1554, 1528, 1499, 1474, 1257, 1202, 1145, 1093, 792, 666, $584,527 \mathrm{~cm}^{-1} ;{ }^{1} \mathrm{H}$ NMR $\left(\mathrm{CDCl}_{3}\right): \delta=8.68\left(1 \mathrm{H}\right.$, br d, $\left.4.4 \mathrm{~Hz},{ }^{\prime \prime}{ }^{\prime}-H\right) ; 8.48(1 \mathrm{H}, \mathrm{d}, 5.7$ $\mathrm{Hz}, 6$ ' $-H), 8.17(1 \mathrm{H}$, br d, J = 8.0 Hz, 3"'-H), $8.11(1 \mathrm{H}, \mathrm{dt}, \mathrm{J}=7.6,1.6 \mathrm{~Hz}, 4$ "' $-H), 8.00$ $\left(1 \mathrm{H}, \mathrm{d}, \mathrm{J}=1.6 \mathrm{~Hz}, 3^{\prime}{ }^{\prime}-H\right), 7.66(1 \mathrm{H}$, br t, J = 6.2 Hz, 5' ' '-H ), $7.42(1 \mathrm{H}, \mathrm{dd}, 5.6,1.6 \mathrm{~Hz}$, $\left.5^{\prime \prime}-H\right), 5.98(2 \mathrm{H}, \mathrm{s}, h f a c), 3.81-3.87(1 \mathrm{H}, \mathrm{m}, 5-H), 3.62(1 \mathrm{H}, \mathrm{dd}, \mathrm{J}=14.2,5.8 \mathrm{~Hz}$, $\left.5 \mathrm{C} H_{\alpha} \mathrm{S}\right), 3.53\left(1 \mathrm{H}, \mathrm{dd}, \mathrm{J}=14.2,8.8 \mathrm{~Hz}, 5-\mathrm{CH}_{\beta} \mathrm{S}\right), 3.42\left(1 \mathrm{H}, \mathrm{dd}, \mathrm{J}=13.6,2.8 \mathrm{~Hz}, 6-H_{\alpha}\right)$, $3.35\left(1 \mathrm{H}, \mathrm{dd}, \mathrm{J}=13.6,4.4 \mathrm{~Hz}, 6-H_{\beta}\right), 3.28\left(4 \mathrm{H}, \mathrm{s}, 5^{\prime}-, 6-H_{2}\right) ;{ }^{13} \mathrm{C}\left\{{ }^{1} \mathrm{H}\right\}$ NMR $\left(\mathrm{CDCl}_{3}\right): \delta=$ $178.7\left(\mathrm{q}, \mathrm{J}_{\mathrm{C}, \mathrm{F}}=33 \mathrm{~Hz}\right.$, hfac 4 x C=O), $154.0\left(2^{\prime}-, 2^{\prime}{ }^{\prime}-C\right), 149.4 \& 148.4\left(6^{\prime}-, 6^{\prime}{ }^{\prime}-C\right)$, 148.2 (4'-C), $140.3\left(4^{\prime \prime}-C\right), 126.9\left(5^{\prime \prime}-C\right), 122.5\left(3^{\prime \prime}-C\right), 121.1$ (5'-C), 117.8 (3'-C), $117.4\left(\mathrm{q}, \mathrm{J}_{\mathrm{C}, \mathrm{F}}=284 \mathrm{~Hz}, \mathrm{hfac}, 4 \times \mathrm{xF}_{3}\right), 114.0,113.7,113.1,112.5,112.1(6 \times \mathrm{SCS}), 89.0$ (hfac, $\left.2 \times C H), 41.0(5-C), 34.9 \& 33.3\left(5-C \mathrm{H}_{2}, 6-C\right) \times \mathrm{SCH}_{2}\right), 30.1\left(5^{\prime}-, 6^{\prime}-C\right) ; \quad m / z$ $\left(\mathrm{ES}^{+}\right): 855,857,859[\mathrm{M}-\mathrm{hfac}]^{+}$. 
A series of further complexes were prepared by the same method in $70-80 \%$ yield.

\section{$\left[\left(\mathbf{L}^{2}\right) \mathbf{M n}(\mathbf{h f a c})_{2}\right]$}

Calc. for $\mathrm{C}_{31} \mathrm{H}_{18} \mathrm{~N}_{2} \mathrm{O}_{4} \mathrm{~F}_{12} \mathrm{~S}_{9} \mathrm{Mn}$ : C 35.33, H 1.72, N 2.66\%; found C 35.62, H 1.67, N $2.49 \% ; v_{\max }(\mathrm{KBr}): 1647,1591,1528,1498,1474,1256,1203,1146,793,664,584$ $\mathrm{cm}^{-1} ; \mathrm{m} / z\left(\mathrm{ES}^{+}\right): 846[\mathrm{M}-\mathrm{hfac}]^{+}$.

\section{$\left[\left(\mathbf{L}^{2}\right) \operatorname{Co}(\mathbf{h f a c})_{2}\right]$}

Calc. for $\mathrm{C}_{31} \mathrm{H}_{18} \mathrm{~N}_{2} \mathrm{O}_{4} \mathrm{~F}_{12} \mathrm{~S}_{9}$ Co: C 35.19, H 1.71, N 2.65\%; found C 35.56, H 1.71, N $2.45 \% ; v_{\max }(\mathrm{KBr}): 1641,1594,1528,1474,1257,1203,1146,793,668,585 \mathrm{~cm}^{-1} ; \mathrm{m} / \mathrm{z}$ $\left(\mathrm{ES}^{+}\right): 850[\mathrm{M}-\mathrm{hfac}]^{+}$.

\section{$\left[\left(\mathbf{L}^{2}\right) \mathbf{N i}(\mathrm{hfac})_{2}\right]$}

Calc. for $\mathrm{C}_{31} \mathrm{H}_{18} \mathrm{~N}_{2} \mathrm{O}_{4} \mathrm{~F}_{12} \mathrm{~S}_{9} \mathrm{Ni}$ : C 35.20, H 1.72, N 2.65\%; found C 35.40, H 1.69, N $2.39 \% ; v_{\max }(\mathrm{KBr}): 1645,1595,1524,1500,1498,1474,1257,1203,1147,792,671$, $587 \mathrm{~cm}^{-1} ; \mathrm{m} / z\left(\mathrm{ES}^{+}\right): 849,851[\mathrm{M}-\mathrm{hfac}]^{+}$.

\section{$\left[\left(\mathbf{L}^{2}\right) \mathbf{C u}(\mathbf{h f a c})_{2}\right]$}

Calc. for $\mathrm{C}_{31} \mathrm{H}_{18} \mathrm{~N}_{2} \mathrm{O}_{4} \mathrm{~F}_{12} \mathrm{~S}_{9} \mathrm{Cu}$ : C 35.04, H 1.71, N 2.64\%, found C 35.33, H 1.70, N $2.49 \%$; $v_{\max }(\mathrm{KBr}): 1670,1662,1654,1650,1598,1550,1528,1491,1258,1203,1147$, 793, 667, $586 \mathrm{~cm}^{-1} ; \mathrm{m} / \mathrm{z}\left(\mathrm{ES}^{+}\right): 854,856[\mathrm{M}-\mathrm{hfac}]^{+}$.

\section{Preparation of $\left[\left(\mathrm{L}^{2}\right) \mathrm{Nd}(\mathrm{hfac})_{3}\right]$}

A solution of $\mathbf{L}^{2}(0.025 \mathrm{~g}, 0.043 \mathrm{mmol})$ in dry $\mathrm{CH}_{2} \mathrm{Cl}_{2}(7 \mathrm{~mL})$ was added to a solution of $\mathrm{Nd}(\mathrm{hfac})_{3} .2 \mathrm{H}_{2} \mathrm{O}(0.034 \mathrm{~g}, 0.042 \mathrm{mmol})$ dissolved in dry acetone $(1.5 \mathrm{~mL})$. The orange solution was heated to reflux for $3 \mathrm{~h}$ under nitrogen followed by stirring for $16 \mathrm{~h}$ at RT. Removal of solvents gave an orange solid which was extracted into a small amount of 
$\mathrm{DCM}, n$-hexane was layered onto the DCM solution and stored overnight at $0^{\circ} \mathrm{C}$. The orange precipitate was collected by filtration washed with n-hexane and dried. Yield $0.046 \mathrm{~g}$, (80\%). Calc. for $\mathrm{C}_{36} \mathrm{H}_{19} \mathrm{~F}_{18} \mathrm{~N}_{2} \mathrm{NdO}_{6} \mathrm{~S}_{9}$ : C 32.02, $\mathrm{H} 1.42, \mathrm{~N} 2.07 \%$, found $\mathrm{C}$ 31.88, H 1.34, N 2.10\%; $v_{\max }(\mathrm{KBr}): 1720,1696,1650,1592,1572,1534,1475,1437$, 1257, 1204, 1147, 1013, 797, 720, 660, $585 \mathrm{~cm}^{-1}$. The solid was insoluble in $\mathrm{MeOH}$, $\mathrm{Et}_{2} \mathrm{O}, \mathrm{CH}_{3} \mathrm{CN}$, soluble in acetone (but slowly decomposes), and less soluble in DCM and $\mathrm{CHCl}_{3}$.

\section{Preparation of $\left[\mathrm{M}\left(\mathrm{L}^{3}\right)_{2}\right]\left(\mathbf{P F}_{6}\right)_{2}$.}

[Zn( $\left.\left.\mathbf{L}^{\mathbf{3}}\right)_{2}\right]\left(\mathbf{P F}_{\mathbf{6}}\right)_{2}$ : A solution of $\mathrm{Zn}(\mathrm{OAc})_{2}(0.013 \mathrm{~g}, 0.056 \mathrm{mmol})$ in $\mathrm{MeOH}(2 \mathrm{~mL})$ was added to a solution of ligand $\mathbf{L}^{3}(0.075 \mathrm{~g}, 0.12 \mathrm{mmol})$ in $\mathrm{CH}_{2} \mathrm{Cl}_{2}(7 \mathrm{~mL})$ and the solution was refluxed for $2 \mathrm{~h}$. After stirring at room temperature overnight, a solution of $\mathrm{NH}_{4} \mathrm{PF}_{6}$ (0.037 $\mathrm{g}, 0.22 \mathrm{mmol})$ in $\mathrm{MeOH}(3 \mathrm{~mL})$ gave instant formation of a yellow precipitate which was stirred for a further $1 \mathrm{~h}$. The yellow solid was collected by filtration, washed with $\mathrm{MeOH}$ and then $\mathrm{CH}_{2} \mathrm{Cl}_{2}$ and dried under vacuum. Yield $0.070 \mathrm{~g}(75 \%)$. Calc. for $\mathrm{C}_{52} \mathrm{H}_{38} \mathrm{~F}_{12} \mathrm{~N}_{6} \mathrm{P}_{2} \mathrm{~S}_{18} \mathrm{Zn}$ : C 37.19, H 2.28, N 5.00\%, found C 37.18, H 2.12, N 4.75\%; . m/z $\left(\mathrm{ES}^{+}\right) 1534\left[\mathrm{M}-\mathrm{PF}_{6}\right]^{+}, 695\left[\mathrm{M}-2 \mathrm{PF}_{6}\right]^{2+} ; v_{\max }(\mathrm{KBr}): 1593,1570,1544,1475,1420,1016$ 841, 788, $558 \mathrm{~cm}^{-1} ;{ }^{1} \mathrm{H}$ NMR $\left(\mathrm{CD}_{3} \mathrm{CN}\right): \delta=8.54\left(\mathrm{~s}, 4 \mathrm{H}, 2\right.$ x $\left.3^{\prime}{ }^{-}, 5^{\prime}-H\right), 8.39(\mathrm{~d}, 4 \mathrm{H}, J=$ $8.0 \mathrm{~Hz}$, major) \& $8.43\left(\mathrm{~d}, 4 \mathrm{H}, J=8.0 \mathrm{~Hz}\right.$, minor) $\left(2 \times 3-, 3^{\prime}{ }^{-}-H\right), 8.08-8.13(\mathrm{~m}, 4 \mathrm{H}, 2 \mathrm{x} 4-$ ,4'’-H), $7.80(\mathrm{~d}, 4 \mathrm{H}, J=4.4 \mathrm{~Hz}, 2$ x 6-,6' $-H), 7.31-7.37(\mathrm{~m}, 4 \mathrm{H}, 2$ x 5-,5' $-H), 4.31-4.38$ (m), 4.20-4.28 (m), 3.62-3.73 (m), 3.48-3.52 (m), 3.12-3.31 (m) (SCH \& 4 x SCH $\mathrm{SH}_{2}$ major and minor diastereomers); ${ }^{13} \mathrm{C}\left\{{ }^{1} \mathrm{H}\right\} \mathrm{NMR}\left(\mathrm{CD}_{3} \mathrm{CN}\right)$ : major diastereomer $\delta=161.1$, $149.4,148.9,148.2,141.6,128.5,123.6,120.3\left(2 \times \mathrm{Ar}-C_{8}\right), 114.0,113.6,112.1,110.6$, 
109.2, 109.1 (6 x sp ${ }^{2} C$, BEDT-TTF), $44.4(\mathrm{SCH}), 35.4\left(\mathrm{SCH}_{2}\right), 33.9\left(\mathrm{SCH}_{2}\right), 30.6$

$\left(\mathrm{SCH}_{2} \mathrm{CH}_{2} \mathrm{~S}\right)$; minor diastereomer $\delta=160.8,149.4,148.9,148.2,141.7,128.5,123.7$, 120.4 ( 2 x Ar- $\left.C_{8}\right), 114.1,113.8,112.5,111.6,109.8,109.6$ (6 x sp² $C$, BEDT-TTF $), 44.1$ $(\mathrm{SCH}), 35.7\left(\mathrm{SCH}_{2}\right), 34.1\left(\mathrm{SCH}_{2}\right), 30.7\left(\mathrm{SCH}_{2} \mathrm{CH}_{2} \mathrm{~S}\right) ;{ }^{31} \mathrm{P}\left\{{ }^{1} \mathrm{H}\right\} \mathrm{NMR}\left(\mathrm{CD}_{3} \mathrm{CN}\right): \delta=-$ 143.17 (septet, $J_{\mathrm{F}-\mathrm{P}}=707 \mathrm{~Hz}, \mathrm{PF}_{6}{ }^{-}$).

The following complexes were prepared following the same general procedure:

$\left[\mathbf{M n}\left(\mathbf{L}^{3}\right)_{2}\right]\left(\mathbf{P F}_{6}\right) 2:$ yellow solid, yield 63\%; Calc. for $\mathrm{C}_{52} \mathrm{H}_{38} \mathrm{~F}_{12} \mathrm{MnN}_{6} \mathrm{P}_{2} \mathrm{~S}_{18} \cdot 2.5 \mathrm{H}_{2} \mathrm{O}, \mathrm{C}$ 36.44, H 2.53, N 4.90\%, found C 36.21, H 2.26, N 4.73\%. m/z $\left(\mathrm{ES}^{+}\right) 691\left[\mathrm{M}-2 \mathrm{PF}_{6}\right]^{2+}$; $v_{\max }(\mathrm{KBr}) \quad 1591,1570,1541,1476,1418,1014,840,788,558 \mathrm{~cm}^{-1}$.

$\left[\mathbf{F e}\left(\mathbf{L}^{\mathbf{3}}\right)_{2}\right]\left(\mathbf{P F}_{6}\right)_{2}$ : from iron(II) chloride, purple solid, yield 82\%; Calc. for $\mathrm{C}_{52} \mathrm{H}_{38} \mathrm{~F}_{12} \mathrm{FeN}_{6} \mathrm{P}_{2} \mathrm{~S}_{18}$ : C 37.40, H 2.29, N 5.03\%, found C 37.38, H 2.40, N 4.97\%; $\mathrm{m} / \mathrm{z}$ $\left(\mathrm{ES}^{+}\right) 1525\left[\mathrm{M}-\mathrm{PF}_{6}\right]^{+} ; v_{\max }(\mathrm{KBr}): 1600,1560,1533,1466,1424,1397,1122,1108$, $840,785,558 \mathrm{~cm}^{-1}$.

[Co( $\left.\left(\mathbf{L}^{\mathbf{3}}\right)_{2}\right]\left(\mathbf{P F}_{6}\right)_{2}$ : light brown solid, yield 73\%; Calc. for $\mathrm{C}_{52} \mathrm{H}_{38} \mathrm{CoF}_{12} \mathrm{~N}_{6} \mathrm{P}_{2} \mathrm{~S}_{18} \cdot \mathrm{H}_{2} \mathrm{O}$ : C 36.94, H 2.38, N 4.97\%, found C 36.76, H 2.19, N 4.83\%; m/z $\left(\mathrm{ES}^{+}\right) 1526[\mathrm{M}-\mathrm{PF} 6]^{+}, 690$ $\left[\mathrm{M}-2 \mathrm{PF}_{6}\right]^{2+} ; v_{\max }(\mathrm{KBr}): 1596,1569,1542,1473,1420,1121,1017,841,787,558 \mathrm{~cm}^{-1}$.

$\left[\mathbf{N i}\left(\mathbf{L}^{\mathbf{3}}\right)_{2}\right]\left(\mathbf{P F}_{6}\right)_{2}$ : orange-yellow solid, yield 57\%; Calc. for $\mathrm{C}_{52} \mathrm{H}_{38} \mathrm{~F}_{12} \mathrm{~N}_{6} \mathrm{NiP}_{2} \mathrm{~S}_{18} . \mathrm{H}_{2} \mathrm{O}$ : C 36.94, H 2.38, N 4.97\%, found C 36.86, H 2.20, N 4.73\%; m/z $\left(\mathrm{ES}^{+}\right) 1525\left[\mathrm{M}-\mathrm{PF}_{6}\right]^{+}, 690$ $\left[\mathrm{M}-2 \mathrm{PF}_{6}\right]^{2+} ; v_{\max }(\mathrm{KBr}): 1595,1570,1543,1474,1420,1016,842,788,558 \mathrm{~cm}^{-1}$.

$\left[\mathbf{C u}\left(\mathbf{L}^{3}\right)_{2}\right]\left(\mathbf{P F}\right.$ )2: light-brown solid, yield 63\%; Calc. for $\mathrm{C}_{52} \mathrm{H}_{38} \mathrm{CuF}_{12} \mathrm{~N}_{6} \mathrm{P}_{2} \mathrm{~S}_{18} \cdot \mathrm{H}_{2} \mathrm{O}$ : C 36.83, H 2.38, N 4.96\%, found C 36.63, H 2.24, N 4.71\%; m/z $\left(\mathrm{ES}^{+}\right) 1532\left[\mathrm{M}-\mathrm{PF}_{6}\right]^{+}, 693$ $\left[\mathrm{M}-2 \mathrm{PF}_{6}\right]^{2+} ; v_{\max }(\mathrm{KBr}): 1595,1571,1542,1474,1420,1020,841,788,558 \mathrm{~cm}^{-1}$. 


\section{Preparation of complexes of ligands $\mathrm{L}^{2}$ with $\mathrm{MnCl}_{2}$ and $\mathrm{CuCl}_{2}$.}

[( $\left.\left.\mathbf{L}^{2}\right) \mathbf{C u C l}_{2}\right]$ : A solution of $\mathrm{CuCl}_{2} \cdot 2 \mathrm{H}_{2} \mathrm{O}(11 \mathrm{mg}, 0.068 \mathrm{mmol})$ in dry $\mathrm{MeOH}(3 \mathrm{~mL})$ was added to a solution of $\mathbf{L}^{2}(40.0 \mathrm{mg}, 0.068 \mathrm{mmol})$ in dry DCM $(10 \mathrm{~mL})$ to give slow formation of a brown precipitate. The mixture was stirred in the dark under a $\mathrm{N}_{2}$ atmosphere for $20 \mathrm{~h}$. The precipitate was collected by filtration, washed with $\mathrm{MeOH}$ and then DCM, and dried under vacuo to give the product as a brown powder, $\quad(0.03 \mathrm{~g}$, 61.4\%). Calc. for $\mathrm{C}_{21} \mathrm{H}_{16} \mathrm{~N}_{2} \mathrm{~S}_{9} \mathrm{CuCl}_{2}$ : C 35.06, H 2.24, N 3.89\%; found C 35.24, H 2.14, N 3.69\%; $m / z\left(\mathrm{ES}^{+}\right): 684[\mathrm{M}-\mathrm{Cl}]^{+}, 584\left[\mathrm{M}-\mathrm{CuCl}_{2}\right]^{+} ; v_{\max }(\mathrm{KBr}): 2915,1594,1569,1534$, $1467,1437,1404,1317,1284,1166,1115,1052,1026,1012,886,818,788,772,718$, $597 \mathrm{~cm}^{-1}$. The solid was insoluble in common organic solvents but reasonably soluble in DMSO and DMF.

$\left[\mathbf{M n}\left(\mathbf{L}^{2}\right)_{2} \mathbf{C l} \mathbf{l}_{2}\right]$ : A solution of $\mathrm{MnCl}_{2} \cdot 4 \mathrm{H}_{2} \mathrm{O}(24.0 \mathrm{mg}, 0.12 \mathrm{mmol})$ in $\mathrm{MeOH}(2 \mathrm{~mL})$ was added to a $\mathrm{CH}_{2} \mathrm{Cl}_{2}(15 \mathrm{~mL})$ solution containing $\mathbf{L}^{2}(0.15 \mathrm{~g}, 0.25 \mathrm{mmol})$ to give an immediate orange precipitate. The mixture was stirred at RT for $2 \mathrm{~h}$ and the solid collected by filtration followed by washing with $\mathrm{MeOH}$ and then $\mathrm{CH}_{2} \mathrm{Cl}_{2}$ and dried under vacuum to give $\left[\left(\mathbf{L}^{2}\right)_{2} \mathrm{MnCl}_{2}\right]$. Yield $0.13 \mathrm{~g}$, (80\%). Calc. for $\mathrm{C}_{42} \mathrm{H}_{32} \mathrm{Cl}_{2} \mathrm{MnN}_{4} \mathrm{~S}_{18}$ : C 38.93, H 2.49, N 4.32\%, found C 38.49, H 2.49, N 4.10\%; m/z (ES+) $585\left[\mathrm{~L}^{2}+\mathrm{H}\right]^{+} ; v_{\max }$ (KBr): 2916, 1590, 1571, 1534, 1473, 1405 ( br), 1314, 1285, 1259, 1118, 1052, 1012 , $818,790,771,714,601 \mathrm{~cm}^{-1}$. 


\section{X-Ray Crystallography.}

$\left[\left(\mathbf{L}^{2}\right)_{3} \mathrm{Fe}(\mathrm{II})\right]_{2} \cdot 4 \mathrm{PF}_{6} \cdot\left(\mathrm{C}_{6} \mathrm{H}_{5} \mathrm{NO}_{2}\right)_{\mathrm{x}} \cdot\left(\mathrm{CH}_{3} \mathrm{OH}\right)_{\mathrm{y}}: \quad$ Diffraction-quality single crystals were obtained from nitrobenzene/methanol. The structure was solved using SHELXS97 ${ }^{36}$ and refined using SHELXL97. ${ }^{36}$ The crystal contained large voids occupied by disordered solvent molecules (methanol and nitrobenzene) and $\mathrm{PF}_{6}{ }^{-}$anions which could not be resolved, so the structure of the cation was refined after application of the SQUEEZE ${ }^{24}$ program to exclude anions and solvents from the model. Both enantiomers of ligand $\mathbf{L}^{2}$ are included in the model, with identical positions for all atoms except those of the substituted ethylene bridge, the side chain methylene carbon and the dithiin sulfur nearest to the substitution position. The unsubstituted ethylene bridge is disordered between two conformations.

Crystal data: $\mathrm{C}_{63} \mathrm{H}_{48} \mathrm{~N}_{6} \mathrm{~S}_{27} \mathrm{Fe} .\left(\mathrm{PF}_{6}\right)_{2}, M_{\mathrm{r}}=2100.48$, trigonal, $a=b=23.8874(12), c=$

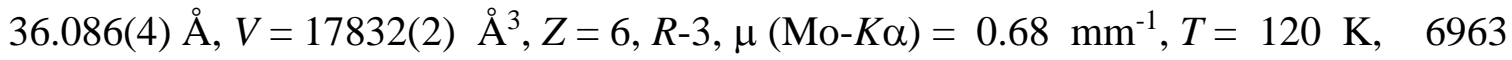
unique reflections, 3760 with $F_{\mathrm{o}}>4 \sigma\left(F_{\mathrm{o}}\right)$, final $R_{1}=0.054 ; w R_{2}=0.14$, crystals from nitrobenzene/methanol. Illustrations were prepared using Mercury, ${ }^{37}$ ORTEP-3 for Windows ${ }^{38}$ and POV-RAY. ${ }^{39}$

Crystal data for $\mathbf{L}^{\mathbf{1}}: \mathrm{C}_{21} \mathrm{H}_{16} \mathrm{~N}_{2} \mathrm{~S}_{9}, M_{\mathrm{r}}=584.9$, monoclinic, $a=17.2349(4), b=17.2808(4)$, $c=7.9477$ (1) $\AA, \beta=92.095(15)^{\mathrm{o}}, V=2365.50(8) \AA^{3}, Z=4$, space group $P 2{ }_{1} / c, D_{\mathrm{c}}=$

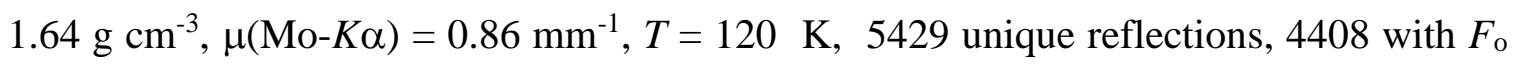
$>4 \sigma\left(F_{\mathrm{o}}\right)$, final $R_{1}=0.044, w R_{2}=0.099$, crystals from DCM/hexane. Crystal data have been deposited at the Cambridge Crystallographic Data Centre with deposition numbers 968626-968627. 
"Supporting Information Available: Listings of NMR and IR spectra for zinc complexes $\left[\left(\mathbf{L}^{2}\right)_{3} \mathrm{Zn}\right]\left(\mathrm{PF}_{6}\right)_{2}, \mathbf{L}^{2} \mathrm{Zn}(\mathrm{hfac})_{2}$ and $\left[\left(\mathbf{L}^{3}\right)_{2} \mathrm{Zn}\right]\left(\mathrm{PF}_{6}\right)_{2}$, tables of cyclic voltammetry data for ligands and complexes and room temperature magnetic moments for complexes, and u.v.visible spectra for $\left[\left(\mathbf{L}^{2}\right)_{3} \mathrm{Fe}\right]\left(\mathrm{PF}_{6}\right)_{2}$, and $\left[\left(\mathbf{L}^{3}\right)_{2} \mathrm{Fe}\right]\left(\mathrm{PF}_{6}\right)_{2}$ This material is available free of charge via the Internet at http://pubs.acs.org."

\section{References and Acknowledgements.}

We thank the Leverhulme Trust for a grant F/01374/B (JW). We thank the EPSRC National Crystallography Service (University of Southampton) and the EPSRC Mass Spectrometry Service (University of Swansea) for measurements. We thank Prof. J. M. Rawson for helpful discussions. We acknowledge the EPSRC Chemical Database Service at Daresbury ${ }^{40}$ for access to the Cambridge Structural Database. ${ }^{14 a}$ The work has benefited from support from ESF COST action D35.

\section{References}

1. (a) Singleton, J.; Mielke, C. Cont. Phys. 2002, 43, 63-96, \& Physics World, 2002, 15, 35-39. (b) Day, P. Comp. Rend. Chem. 2003, 6, 301-308.

2. (a) Williams, J. M.; Schultz, A. J.; Geiser, U.; Carlson, K. D.; Kini, A. M.; Wang, H. M.; Kwok, W. K.; Whangbo, M. H.; Shirber, J. E. Science 1991, 252, 1501-1508. (b) Whangbo, M. H.; Torardi, C. C. Acc. Chem. Res. 1991, 24, 127-133. (c) Ishiguro, T.; Yamaji, K.; Saito, G. "Organic

Superconductors”, Springer Verlag, Berlin, 1998. (d) Mori, H. J. Phys. Soc. Jpn. 2006, 75, 051003/1-15.

3. Lunkenheimer, P.; Hartmann, B.; Lang, M.; Mueller, J.; Schweitzer, D.; Krohns, S.; Loidl, A. Phys. Rev. B 2015, 91, 245132/1-245132/7. 
4. Itahara, H.; Maesato, M.; Asahi, R., Yamochi, H., Saito, G; J. Electron. Mater., 2009, 38, 1171-1175.

5. Konarev, D. V.; Kovalevsky, A. Yu.; Coppens P.; Lyubovskaya, R. N.; Chem. Commun., 2000, 2357-2358.

6. Laukhina, V.; Laukhina, E.; Lebedev, V.; Rovira, C.; Veciana, J. Proced. Eng. 2014, 87, 1135 - 1138 .

7. Chtioui-Gay, I.; Faulmann, C.; de Caro, D.; Jacob, K.; Valade, L.; de Caro, P.; Fraxedas, J.; Ballesteros, B.; Steven, E.; Choi, E. S.; Lee, M.; Benjamin, S. M.; Yvenou, E.; Simonatof, J.-M.; Carellaf, A. J. Mater. Chem. 2016, Advance Article, July 2016.

8. (a) Kurmoo, M.; Graham, A. W.; Day, P.; Coles, S. J.; Hursthouse, M. B.; Caulfield, J. L.; Singleton, J.; Pratt, F. L.; Hayes, W.; Ducassse, L.; Guionneau, P. J. Amer. Chem. Soc. 1995, 117, 12209-12217. (b) Prokhorova, T. G.; Zorina, L. V.; Simonov, S. V.; Zverev, V. N.; Canadell, E.; Shibaeva, R. P.; Yagubskii, E. B. CrystEng Comm. 2013, 15, 7048-7055. (c) Coronado, E.; Curreli, S.; Giménez-Saiz, C.; Gómez-García, C. J. Inorg. Chem., 2012, 51, 1111-1126.

9. (a) Coronado, E.; Galán-Mascaros, J. R.; Gomez-Garcia, C. J.; Laukhin, V. Nature 2000, 408, 447-449. (b) Coronado, E.; Day, P. Chem. Rev., 2004, 104, 5419-5448. (c) Coronado, E.; Galán-Mascaros J.R. J. Mater. Chem. 2005, 15, 66-74.

10. (a) J.R. Lopez, L. Martin, J.D. Wallis, H. Akutsu, Y. Nakazawa, J.-I. Yamada, T. Kadoya, S.J. Coles, C. Wilson, Dalton Trans, 2016, 45, 92859293. (b) Martin, L.; Akutsu, H.; Horton, P.N.; Hursthouse, M.B.; Harrington, R.W.; Clegg, W. Eur. J. Inorg. Chem. 2015, 1865-1870. (c) Coronado, E.; Galan-Mascaros, J.R.; Gomez-Garcia, C.J.; Murcia-Martinez, A.; Canadell, E. Inorg. Chem. 2004, 43, 8072-8077.

11. (a) Mori, T. Bull. Chem. Soc. Jpn. 1998, 71, 2509-2526. (b) Mori, T.; Mori, H.; Tanaka, S. Bull. Chem. Soc. Jpn. 1999, 72, 179-197. (c) Mori, T. Bull. Chem. Soc. Jpn. 1999, 72, 2011-2027.

12. (a) Krivickas, S.J., Hashimoto, C.; Yoshida, J.; Ueda, A.; Takahashi, K.; Wallis J. D.; Mori, H. Beil. J. Org. Chem., 2015, 11, 1561-1569. (b) S. Yang, F. Pop, C. Melan, A.C. Brooks, L. Martin, P. Horton, P. AubanSenzier, G. L.J.A. Rikken, N. Avarvari, J. D. Wallis, CrystEngComm., 2014, 16, 3906-3916.

13. Guionneau, P.; Chasseau, D.; Howard, J.A.K.; Day, P. Acta Crystallogr. 2000, C56, 453-454; Pop, F.; Laroussi, S.; Cauchy, T.; Gomez-Garcia, C. J.; 
Wallis, J. D. ; Avarvari, N. Chirality, 2013, 25, 466-474.

14. (a) Data from the Cambridge Structural Database: Allen, F. H. Acta Crystallogr. 2002, B58, 380-388. (b) refcode FETMIC, (BEDTTTF $)_{2} \mathrm{~B}_{5} \mathrm{O}_{6}(\mathrm{OH})_{4}$, Brooks, A.C.; Martin, L.; Day, P.; Lopes, E.B.; Almeida, M.; Kikuchi, K.; Fujita, W.; Sasamori, K.; Aktusu H.; Wallis, J.D. Dalton Trans. 2013, 42, 6645-6654. (c) refcode GAMFIJ20, (BEDT-TTF) $)_{2} \mathrm{Cu}(\mathrm{NCS})_{2}$ Hiramatsu, T.; Yoshida, Y.; Saito, G.; Otsuka, A.; Yamochi, H.; Maesato, M.; Shimizu, Y.; Itoe, H.; Kishida, H. J. Mater. Chem. C. 2015, 3, 1378-1388.

15. (a) Avarvari, N.; Wallis, J. D. J. Mater. Chem. 2009, 19, 4061-4076. (b) Griffiths, J.-P.; Wallis, J. D. J. Mater. Chem. 2005, 15, 347-365. (c) Brown, R. J.; Brooks, A. C.; Griffiths, J.-P.; Vital, B.; Day, P.; Wallis, J. D. Org. Biomolec. Chem. 2007, 5, 3172-3182. (d) Yang, S.; Brooks A. C.; Martin, L.; Day, P.; Pilkington, M.; Clegg, W.; Harrington, R. W.; Russo, L.; Wallis, J. D. Tetrahedron, 2010, 66, 6977-6989.

16. Griffiths, J.P.; Brown, R. J.; Day, P.; Matthews, C. J.; Vital, B.; Wallis, J. D. Tetrahedron Lett. 2003, 44, 3127-3131.

17. Wang, Q.; Nie, H.; Griffiths, J.-P.; Day, P.; Wallis J. D. New J. Chem. 2006, 1790-1800.

18. (a) Iwahori, F.; Golhen, S.; Ouahab, L.; Carlier, R.; Sutter, J.-P. Inorg. Chem. 2001, 40, 6541-6542. (b) Setifi, F.; Ouahab, L.; Golhen, S.; Yoshida, Y.; Saito G. Inorg. Chem. 2003, 42, 1791-1793. (c) Goldenberg, L. M.; Becker, J. Y.; Levi, O. P.-T.; Khodorkovsky, V. Y.; Bryce, M. R.; Petty, M. C. J. Chem. Soc., Chem. Commun. 1995, 475-476. (d) Brooks, A. C.; Day, P.; Dias, S. I. G.; Rabaca, S.; Santos, I. C.; Henriques, R. T.; Wallis, J. D.; Almeida, M. Eur. J. Inorg. Chem. 2009, 3084-3093. (e) Pop, F.; Ding, J.; Daku, L. M. L.; Hauser, A.; Avarvari, N. RSC Advances, 2013, 3, 3218-3221. (f) Li, G.N.; Wen, D.; Jin, T.; Liao, Y.; Zuo, J.-L.; You, X.-Z. Tetrahedron Lett., 2011, 52, 675-678. (g) Hu, L.; Liu, W.; Li, C.-H.; Zhou, X.-H.; Zuo, J.L. Eur. J. Inorg. Chem., 2013, 6037-6048.

19. (a) Fourmigué, M.; Batail, P. J. Chem. Soc. Chem. Commun. 1991, 13701372. (b) Fourmigué, M.; Uzelmeier, C. E.; Boubekeur, K.; Bartley, S. L.; Dunbar, K. R. J. Organomet. Chem. 1997, 529, 343-350. (d) Avarvari, N. ; Fourmigué, M. Chem. Commun. 2004, 1300-1301.

20. Réthoré, C.; Suisse, I.; Agbossou-Niedercorn, F.; Guillamón, E.; Llusar, R.; Fourmigué, M.; Avarvari, N. Tetrahedron 2006, 62, 11942-11947.

21. (a) Devic, T.; Avarvari, N.; Batail, P. Chem. Eur. J. 2004, 10, 3697-3707; (b) Devic, T.; Rondeau, D.; Şahin, Y.; Levillain, E.; Clérac, R.; Batail, P.; Avarvari N. Dalton Trans. 2006, 1331-1337. 
22. Chahma, M.; Wang, X. S.; van der Est, A.; Pilkington, M. J. Org. Chem. 2006, 71, 2750-2755.

23. Lorcy, D.; Bellec, N.; Fourmigué, M.; Avarvari, N. Coord. Chem. Rev. 2009, 253, 1398-1438.

24. Spek, A. L. Acta Crystallogr., Sect. D 2009, 65, 148-155.

25. (a) Nyburg, S. C.; Faerman, C. H. Acta Crystallogr., Sect. B. 1985, 41, 274279. (b) Hudson, R. F.; Wallis, J. D. Heterocycles, 1994, 1933-1950.

26. Cannizzo, A.; Milne, C. J.; Consani, C.; Gawelda, W.; Bressler, C.; van Mourik, F.; Chergui, M Coord. Chem. Rev., 2010, 254, 2677-2686.

27. (a) Hadadzadeh, H.; Mansouri, G.; Rezvani, A.; Khavai, H. R.; Skelton, B.W.; Makha, M.; Charati, F. R. Polyhedron, 2011, 30, 2535-2543. (b) Zerara, M.; Hauser, A. ChemPhysChem, 2004, 5, 395-399.

28. (a) Ballester, P. Chem. Soc. Rev. 2010, 39, 3810-3830. (b) Conn, M. M.; Rebek, J. Jr. Chem. Rev., 1997, 97, 1647-1668.

29. (a) Mendoza, S.; Godinez, L. A.; Kaifer, A. E. Supramol. Chem. 2004, 16, 165-169. (b) Frei, M.; Diederich, F.; Tremont, R.; Rodriguez, T.;

Echegoyen, L. Helv. Chim. Acta 2006, 89, 2040-2057. (c) Lyskawa, J.; Sallé, M.; Balandier, J. Y.; Le Derf, F.; Levillain, E.; Allain, M.; Viel P.; Palacin, S. Chem. Commun. 2006, 2233-2235. (d) Zhao, B. T ; Blesa, M. J.; Mercier, N.; Le Derf, F.; Sallé, M. Supramol. Chem. 2005, 17, 465-468.

30. Canevet, D.; Sallé, M.; Zhang, G.; Zhang, D.; Zhu, D. Chem. Commun. 2009, 2245-2269.

31. (a) Ota, A.; Ouahab, L.; Golhen, S.; Cador, O.; Yoshida, Y.; Saito, G. New. J. Chem. 2005, 29, 1135-1140. (b) Rabu, P.; Drillon, M.; Iwamura, H.; Görlitz, G.; Itoh, T.; Matsuda, K.; Koga, N.; Inoue, K. Eur. J. Inorg. Chem. 2000, 211-216. (c) Okada, K.; Nagao, O.; Mori, H.; Kozki, M.; Shiomi, D.; Sato, K.; Takui, T.; Kitagawa, Y.; Yamaguchi, K. Inorg. Chem. 2003, 42, 3221-3228. (d) Kumada, H.; Sakane, A.; Koga, N.; Iwamura, H. Dalton Trans. 2000, 911-914. (e) Hicks R. G.; Lemaire, M. T.; Thompson, L. K.; Barclay, T. M. J. Amer. Chem. Soc. 2000, 122, 8077-8078. (f) Barclay, T. M.; Hicks, R. G.; Lemaire, M. T.; Thompson, L. K. Inorg. Chem. 2001, 40, 55815584.

32. McCann, S.; McCann, M.; Casey, R. M. T.; Jackman, M.; Devereux, M.; McKee, V. Inorg. Chim. Acta 1998, 279, 24-29. 
33. (a) Wysocki, W.; Branowska, D.; Urbanczyk-Lipkowska, Z.; Karczmarzyk, Z. X-ray Structure Analysis Online, 2006, 22, x51-x52. (b) Constable, E. C.; Housecroft, C. E.; Neuburger, M.; Price, J. R.; Zampese, J. A. CrystEngComm 2010, 12, 2928-2937. (c) Constable, E. C.; Housecroft, C. E.; Neuburger, M.; Price, J. R.; Zampese, J. A. Aust. J. Chem. 2010, 63, 13341341.

34. Griffiths, J.-P.; Arola, A. A.; Appleby, G.; Wallis, J. D. Tetrahedron Lett., 2004, 45, 2813-2816.

35. (a) Kilner, C.A.; Halcrow, M.A. Dalton Trans, 2010, 39, 9008-9012. (b) Enachescu, C.; Krivokapic, I.; Zerara, M.; Real, J.A.; Amstutz, N.; Hauser, A. Inorg. Chim. Acta 2007, 360, 3945-3950.

36. Sheldrick, G. M. Acta Crystallogr. Sect. A 2008, 64, 112-122.

37. Macrae, C. F.; Edgington, P. R.; McCabe, P.; Pidcock, E.; Shields, G. P.; Taylor, R.; Towler, M.; van de Streek, J. J. Appl. Crystallogr. 2006, 39, 453-457.

38. Farrugia, L. J. J. Appl. Crystallogr. 1997, 30, 565-565.

39. Persistence of Vision Pty. Ltd. (2004). Persistence of Vision (TM) RaytracePersistence of Vision Pty. Ltd., Williamstown, Victoria, Australia, http://www.povray.com/accessed 6 November 2011

40. Fletcher, D. A.; McMeeking, R. F.; Parkin, D. "The United Kingdom Chemical Database Service", J. Chem. Inf. Comput. Sci. 1996, 36, 746-749. 


\section{For Table of Contents Only}
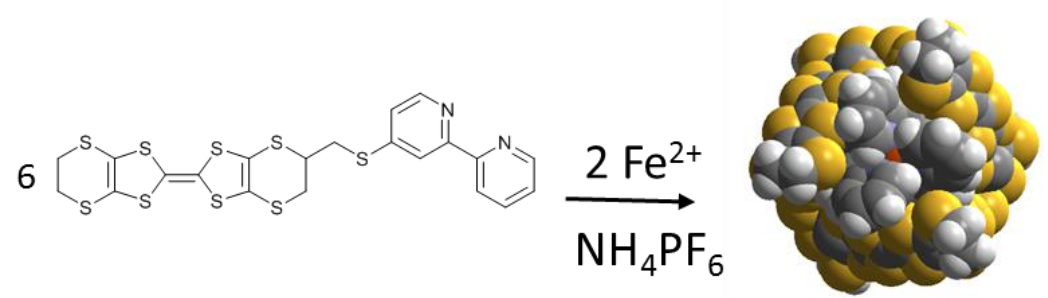

BEDT-TTF functionalized with a 2,2'-bipyridin-4-thiomethyl side chain reacts with $\mathrm{Fe}$ (II) to form a capsule structure, characterized by X-ray crystallography, which is composed of two tris(ligand)Fe(II) complexes which are organized so that the ends of the sulfur donors from one complex lie in the clefts between bipy units on the second donor and vice-versa. Further coordination chemistry of this ligand and of the corresponding 4'terpy ligand with transition metal ions is reported. 